

\title{
Kant, governamentalidade e crítica
}

\author{
Jorge Alberto Rocha
}

\section{SciELO Books / SciELO Livros / SciELO Libros}

ROCHA, JAC. Kant, governamentalidade e crítica. In: Michel Foucault: crítico-esteta-cínico mitigado [online]. Campina Grande: EDUEPB, 2014. Substractum collection, pp. 81-152. ISBN 978-85-7879-

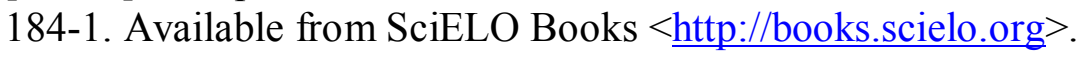

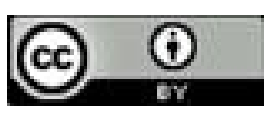

All the contents of this work, except where otherwise noted, is licensed under a Creative Commons Attribution $\underline{4.0 \text { International license. }}$

Todo o conteúdo deste trabalho, exceto quando houver ressalva, é publicado sob a licença Creative Commons Atribição 4.0.

Todo el contenido de esta obra, excepto donde se indique lo contrario, está bajo licencia de la licencia $\underline{\text { Creative }}$ Commons Reconocimento 4.0. 


\section{Kant, governamentalidade e crítica}

Kraemer buscou em pesquisa recente (2011, p. 27) perceber como Kant aparece na obra de Michel Foucault. Para ele, essa ocorrência se dá, sobretudo, em "quatro textos 'menores'" e em uma obra específica. A saber: na assim chamada "tese complementar" do seu doutorado (2002), ${ }^{26} \mathrm{em}$ "Qu'est-ce que les Lumières" (DE, IV, 1994), em "What is Enlightemment? [“Qu'est-ce que les Lumières?]” (DE, IV, 1994) e em“Qué es la Crítica? [Crítique y Aufklärung]" (1995) - os textos menores - além de inúmeras referências encontradas no livro Les mots et les choses. Não é o caso aqui retomar todos esses momentos. Limita-se na presente tese a destacar apenas os episódios fundamentais em que Kant é tomado por aquele dentro do aspecto crítico que este inaugura, ou seja, tematizando constantemente o significado e projeções da Aufklärung, a partir da visão foucaultiana. ${ }^{27}$

26 Esta tese complementar à sua tese principal de doutorado, na nossa edição de 2002, não traz o texto datilografado original, incluindo-se aqui apenas a breve "Notice historique", onde Foucault menciona algumas condições e período de escrita no texto.

27 Na análise de Kraemer (2011, p. 265), vai haver um hiato das atenções foucaultianas voltadas para a Aufklärung de 1966 a 1978, quando "não se encontraram referências de Foucault" acerca desse tema. 
No texto "Que es la Crítica? [Crítique y Aufklärung]" (FOUCAULT, 1995, p. 4) Michel Foucault tenta mostrar que houve como uma das características da cultura ocidental o "jogo da governamentalização e da crítica". E que Kant, ao pensar na Aufklärung, na verdade inaugurou essa postura, ideia que o coloca como uma espécie de divisor de águas. Esse pensamento, sem o aporte ao tema da Aufklärung, já tinha inclusive sido colocado por Foucault: "À dinastia helênica, que se estende de Hölderlin a Heidegger, opôs-se à dinastia dos modernos Aufklärer, que iria de Marx a LéviStrauss" (FOUCAULT, "Une histoire restée muette", DE, I, 1994, p. 547).

Foucault se endereça ao público na referida conferência dizendo que não é da sua pretensão "retomar (...) o projeto crítico kantiano em todo o seu rigor filosófico"; em um auditório de filósofos isso era algo impróprio, "não sendo eu mesmo disse ele - filósofo, senão apenas crítico" (FOUCAULT, 1995, p. 6). É interessante notar que o aspecto crítico em Kant acima pontuado só aparece em Foucault com todas as suas conotações positivas após uma posição negativa, por assim dizer, atribuída este. Duas foram, portanto, as leituras principais feitas por Foucault ao legado kantiano: a sua posição voltada para uma espécie de "antropologismo"; e o empreendimento da obra Kantiana como quem inaugurou a herança crítica do Ocidente. De um lado, o da posição negativa reputada ao filósofo alemão, analisada sob o viés de um procedimento "arqueológico"; de outro, uma tendência das mais valoradas, pois abrirá o caminho para a constituição foucaultiana da sua própria empresa crítica. Entender preliminarmente o primeiro momento negativo serve como auxilio para compreender o teor da reviravolta interpretativa foucautiana. 


\section{Duas leituras de Kant}

Les mots et les choses, publicada em 1966, foi uma obra na qual Foucault investiga as práticas discursivas. Até os anos 70 Foucault vai se valer, do ponto de vista metodológico, de uma investigação muito particular, chamada de "arqueológica", que, além de ser exposta em detalhes na obra L'archéologie du savoir, publicada nos idos de 1969, também aparece nos Dits et écrits de forma abundante, como se viu no primeiro Capítulo desta tese. Em Les mots et les choses a referência a Kant tenderá para dois aspectos importantes: para a colocação kantiana do par conhecimento-finitude, e para a inserção do seu empreendimento no criticável espaço da "antropologia". Essa analítica foucaultiana vai colocar o problema dos limites da razão e do antropologismo em Kant, questões que estarão no âmago do seu personagem conceitual crítico.

Les mots et les choses pergunta em geral pela forma de como os discursos são ordenados. Ou seja, de como as palavras e as coisas podem se juntar ou encontrar uma correspondência entre si. Foucault se empenha por mostrar, nos vários segmentos da história, as leis da sua ordem, e o faz através da noção de "epistémê".${ }^{28}$ Há, na classificação do autor, uma epistémê pré-clássica, clássica e moderna (esta última alocada por

28 Foucault entende por epistémê "o dispositivo estratégico [especificamente discursivo, nesse caso] que permite classificar entre todos os enunciados possíveis aqueles que vão poder ser aceitos no interior, eu não digo de uma teoria científica, mas de um campo de cientificidade, $\mathrm{e}$ do qual se poderá dizer: este é verdadeiro ou falso. É o dispositivo que permite separar, não o verdadeiro do falso, mas o inqualificável cientificamente do qualificável" (FOUCAULT, "Le jeu de Michel Foucault, DE, III, 1994, p. 301). 
Kant), ancorando tais estudos até por volta de 1950. No final desse texto, cujas imprecisões e lacunas a crítica intelectual e jornalística não deixou em branco, uma idéia em particular vai sobressair: a de que o homem talvez fosse apenas um episódio rápido no cenário do saber; que, afinal, tornar-se-ia quiçá apenas um rosto de areia desenhado na orla do mar, pronto a se apagar ao fluxo das ondas:

Se estas disposições viessem a desaparecer tal como elas apareceram, se, por algum acontecimento do qual nós podemos quando muito pressentir a possibilidade, mas de que não conhecemos por um instante ainda nem a forma nem a promessa, se apagassem, como aconteceu, na curva do século XVIII, com o solo do pensamento clássico, - então pode-se apostar que o homem se desvanesceria, como, na orla do mar, um rosto de areia (FOUCAULT, 2002a, p. 398).

Não se tratava para Foucault do fim ou da morte do homem como tal. O que ele quis dizer era que, se o homem "não existia" até o século XVIII, mesmo nas discussões sobre o problema das raças, devia-se isto ao fato de o mesmo não estar incluído no horizonte epistemológico da época; segundo, se, no final desse período, ele vai surgir como aquilo do qual era "necessário pensar" e se "devia saber" (FOUCAULT, 2002a, p. 319), por que sacralizar esse episódio como sendo definitivo? Até que ponto a pesquisa acerca de tal objeto lograra êxito, no sentido de um homem doravante apreendido, compreendido, instalado na nudez de um saber que o dissecou, sem que 
tais esforços se furtassem em seguida, e com quantas ilusões, a fazer seus prognósticos, inclusive nos campos ético, social e político?

As análises foucaultianas que tratam dessa curva operada no fim do século XVIII não vão ser consoladoras. Se até então representar como um "quadro" era o espaço do saber clássico, se não existia fissuras entre as coisas, a linguagem e a representação daquelas - por exemplo, a filosofia cartesiana não poria nenhum obstáculo entre a passagem do "eu penso" para o "eu sou" (FOUCAULT, 2002a, p. 322) - algo novo se anunciava, pondo limites à representação. O surgimento de ciências positivas ou de novas empiricidades (da história natural para a biologia, da análise das riquezas para a economia, da reflexão sobre a linguagem para a filologia); da literatura, fazendo dispensável a figura do homem; o retorno da filosofia sobre seu devir (o que é para o pensamento ter uma história?); a história como tal, ao mesmo tempo saber específico e modo de ser das empiricidades (FOUCAULT, 2002a, p. 233) - tudo isso vai operar um deslocamento no cenário do saber.

Essas mutações tinham a ver com aquilo que Foucault chamou de "analítica da finitude", já aí sendo anunciado algo relativo ou ligado ao "destino do pensamento moderno" (FOUCAULT, 2002a, p. 326). Ou seja, a ideia era a de que o pensamento clássico trabalhava sempre com o par finitude -infinito. Como disse Deleuze, "as forças do homem entram em relação com forças de elevação ao infinito", não resultando uma forma-homem, mas uma forma-Deus (DELEUZE, 1988, p. 133). Daí se reafirmar que o "homem" não existia. No entendimento de Foucault esse homem, deslocado do centro do saber no mundo clássico, era tanto cioso dos seus limites 
- viver uma existência animal, trabalhar arduamente, pensar com "palavras opacas" - quanto, por essa mesma razão, impossibilitado de conhecer ora os mecanismos de seu corpo, ora os meios de satisfazer as suas necessidades ou o método para pensar sem o perigoso auxílio de uma linguagem toda tramada de hábitos e imaginações. Então, diz ele, uma metafísica era não apenas possível, mas também exigida nessa epistémê, tendo o infinito como seu grande horizonte.

Uma nova configuração epistêmica desse "homem" vai surgir. Foucault fala aí dos seus três "duplos" ou "modos de ser", a partir de então o possibilitando, num só lance, tanto recusar uma filosofia fenomenológica da consciência, quanto as aporias do marxismo e do positivismo, caminhos abertos, nas palavras de Lebrun, para se "transgredir a finitude" (LEBRUN, 1985, p. 23). No primeiro caso, ainda no contexto de Les mots et les choses, aparece sua descrição acerca do "vivido" como expressão exemplar dessa tendência, onde a tenção entre uma experiência do corpo e a cultura seguiriam tal linha:

Ela [a Fenomenologia] busca articular a objetividade possível de um conhecimento da natureza sobre a experiência originária que se esboça através do corpo; e a articular a história possível de uma cultura sobre a condensação semântica que ao mesmo tempo se esconde e se mostra na experiência vivida (FOUCAULT, 2002a, p.332).

O primeiro duplo: o homem aparece como um "estranho" par empírico-transcendental. Ele será a um tempo objeto de pesquisa e sujeito da investigação, aquele que detém em si 
a possibilidade do conhecimento (transcendental). $\mathrm{Ou}$, como escreveu Foucault, "soberano submisso, espectador observado" (FOUCAULT, 2002a, p. 323), posição que lhe conferirá um estatuto algo ambíguo. Nesse sentido, pouco importará onde estarão depositados os conteúdos do conhecimento: memória, imaginação, percepção etc. Importará "pôr em jogo as condições do conhecimento, a partir dos conteúdos empíricos que estão dados nela" (FOUCAULT, 2002a, p. 329). ${ }^{29}$

O retorno ao "vivido" não é, porém, o cerne maior de contestação do positivismo e da escatologia. Para Foucault o problema está em não ter posto devidamente a questão do homem, ou melhor, da morte do homem, talvez "aberrante" à primeira vista e, entretanto, muito bem delineada pelo pensamento de Nietzsche. Críticas importantes de Foucault aparecem aí. O super-homem nietzscheano fala de um "retorno", cujo sinal era justamente esse homem há tempos já desaparecido, na luz fosca de uma modernidade solícita para com ele, de um humanismo adormecido "serenamente sobre sua murmurante inexistência" (FOUCAULT, 2002a, p. 333). De uma modernidade que desconheceu o "abismo" falado por Nietzsche, ilustrada por aquela referência do homem como "corda estendida entre o animal e o Super-humano" (NIETZSCHE, 2000, p. 25).

29 Quais são esses conteúdos no seu início? O primeiro estaria ligado ao espaço do corpo, ao estudo dos seus mecanismos perceptivos, neuromotores, e sua relação com o mundo físico. Descobre-se, então, nessa espécie de "estética transcendental", que o conhecimento tem condições "anátomofisiológicas", que há uma "natureza" do conhecimento. O segundo conteúdo tem a ver com algo parecido a uma "dialética transcendental": o conhecimento tem condições históricas, sociais ou econômicas, e disso derivam as relações humanas. $\mathrm{Ou}$, o que dá no mesmo, o conhecimento é histórico. 
Um homem que desaparece até na literatura. Nietzsche abre o caminho para a linguagem em sua "multiplicidade enigmática". Os esforços para contê-la, como a formalização universal dos discursos, a "exegese integral do mundo" ou uma "teoria geral dos signos" (FOUCAULT, 2002a, p. 316) não reconduziram à unidade o ser fragmentado da linguagem. Antes, diz Foucault, o reenvio do signo ao "quem fala?" nietzscheano, vide o que encontramos em Para a genealogia da moral (NIETZSCHE, 1983), rumo à proposta de Mallarmé de "apagar-se ele mesmo na sua própria linguagem, ao ponto de não mais querer figurar aí senão a título de executor numa pura cerimônia do Livro, onde o discurso se comporia por si mesmo" (FOUCAULT, 2002a, p. 317), são também expressões de mais um caso de deslocamento do homem como figura central. ${ }^{30}$

O segundo duplo é constituído pelo par cogito-impensado: ora, como desdobramento do par empírico-transcendental o homem vai situar-se entre aquilo que ele pensa (o cogito) e aquilo que o escapa; ou, melhor ainda, no cerne mesmo do seu pensamento, sem fissuras, evidente à primeira vista, um impensado surgirá, mostrando que o cogito era apenas uma dobra desse desconhecido que o habitava, sua face mais evidente e menor. Doravante, a tarefa de um questionamento interno e desconcertante não poderá mais ser encoberto: afinal, quem é este homem que vive, trabalha e fala, ao mesmo tempo sem dominar suas pulsões mais íntimas, as leis e exigências de seu trabalho, a própria linguagem que possibilita

30 O tema do desaparecimento do homem na literatura e, para além disso, de tudo o que ela representava, passa pela compreensão e valorização foucaultianas de autores como o citado Mallarmé, mais Sade, Kafka, Bataille, Blanchot e outros (MACHADO, 2000). 
seu discurso, e não obstante que se formou sem ele há séculos (FOUCAULT, 2002a, p. 334) $?^{31}$

Antes e com Kant perguntava-se: como é possível o conhecimento? Agora: como se dá esse desconhecido primeiro e fundante? Assim, pensa Foucault, vai haver um "deslocamento [déplacement] da questão transcendental" (FOUCAULT, 2002a, p. 334), marcando uma distância tanto da análise kantiana, quanto do sentido cartesiano dado ao cogito. No caso de Descartes este teria elevado o pensamento àquilo que o distinguia do erro ou da ilusão (bastava ser claro e distinto na sua forma). Agora, pelo "cogito moderno", a distância entre o pensamento e o impensado está posta num movimento de separação e religamento: o impensado é, como tal, um não pensamento; porém, aquele não é estranho a este, antes "se enraíza" nele e se coloca mesmo como sua morada. Conseqüência disso tudo? - o "eu penso" não conduz ao "eu sou". A solidez afirmativa do "ser" em Descartes se esboroa para deixar em aberto este outro ser (do homem), que "está em questão":

Que é, pois, esse ser que cintila e, por assim dizer, tremeluz na abertura do cogito, mas não está dado soberanamente nele e por ele? Que é o ser do homem, e como pode ocorrer que esse ser, que se poderia tão facilmente caracterizar pelo

31 Para Michel Foucault o "projeto fenomenológico" ao surgir não marca nenhuma novidade. Apenas é o testemunho dessa virada do saber do final do século XIX, ao oscilar entre a "descrição do vivido", como tal empírica, e uma "ontologia do impensado que põe fora de circuito a primazia do 'eu penso' (FOUCAULT, 2002a, p. 336). 
fato de que 'ele tem pensamento' e que talvez só ele o possua, tenha uma relação indelével e fundamental com o impensado (FOUCAULT, 2002a, p. 336)?

O terceiro e último traço que caracteriza em conjunto o pensamento ou reflexão e o ser do homem é, em Les mots et les choses, o retorno e o recuo da origem. O que se vê aqui é novamente uma analítica foucaultiana na direção de uma recusa de algo como uma autonomia do sujeito, já que "o originário no homem é isso que, entrando em jogo, o articula sobre outra coisa que ele mesmo; é o que introduz em sua experiência conteúdos e formas mais antigas que ele e que ele não domina" (FOUCAULT, 2002a, p. 342, grifo nosso). Essa “outra coisa" é a história, ou, mais propriamente, a historicidade, tanto no sentido daquilo que envolve a vida, o trabalho e a linguagem, quanto mostrando que o homem é "o ser sem origem" (FOUCAULT, 2002a, p. 342), que ele não pode ser contemporâneo desse "já começado". Em outras palavras, a experiência humana se desenvolve no solo de tal historicidade; mas esta, já feita, existindo antes do sujeito, tanto se "esboça" quanto se "esquiva".

Em todo caso, tal problema não poderia cessar os esforços do pensamento. Ao contrário, a preocupação com o retorno será traço da modernidade, vide Hegel, Marx ou Spengler, com todo o desfecho "feliz" dessa odisséia humana pela história, por exemplo, passando por Hölderlin, Nietzsche e Heidegger - embora, dessa vez, em oposição àquela espécie de retorno, a "evasão dos deuses", o "crescimento do deserto", a "dominação da vontade pela tékhnê" fossem, respectivamente, seus aportes ao tema do retorno. Bem entendido, tematizar o retorno significa conduzir o pensamento para a região do "Mesmo", da identidade. Porém, o que sobra desse idêntico não é uma 
origem fixa e destacada, como um marco zero, mas, expressão da finitude do homem, um ser do qual não se pode destacar sua relação com a temporalidade, e em igual movimento seu estranhamento diante desse algo já começado (FOUCAULT, 2002a , p. 343-346). No solo desse modo de ser do homem é que se puderam formar as ciências humanas, justamente por isso não conseguindo apreendê-lo de uma forma menos evasiva. ${ }^{32}$

As premissas postas por Les mots et les choses trazem nesse instante uma conclusão inevitável e importante. Na síntese de Foucault, "A cultura ocidental constituiu, sob o nome de homem, um ser que, por um só e mesmo jogo de razões, deve ser domínio positivo do saber e não pode ser objeto de ciência" (FOUCAULT, 2002a, p. 378, grifo nosso). Em outras palavras, “O antropologismo é em nossos dias o grande perigo interior do saber" (FOUCAULT, 2002a, p. 359). Ora, as ciências estrito senso sempre tentaram trabalhar com o elemento da universalidade. As ciências humanas prendem-se, porém, desde o seu nascimento, e de forma inescapável, ao "acontecimento", à historicidade, história que se situa em Foucault não como uma disciplina qualquer na vizinhança de outras tantas, mas como seu solo a um tempo estranho, indefinido e fundamental, e que vai compor o caráter finito do homem.

já que o ser humano tornou-se de parte a parte histórico, nenhum dos conteúdos analisados pelas ciências humanas pode permanecer estável nela mesma nem escapar ao movimento da História.

32 As páginas seguintes de Les mots et les choses são atentas às explicações disso, que foje agora aos propósitos da presente tese. 
Ser finito seria, muito simplesmente, ser tomado pelas leis de uma perspectiva que ao mesmo tempo permite uma certa apreensão - do tipo da percepção ou da compreensão - e impede que esta jamais seja intelecção universal e definitiva (FOUCAULT, 2002a, p. 384).

É assim que as críticas foucaultianas mostram o aparecimento e a diluição da perspectiva filosófica kantiana. Em Les mots et les choses a antropologia não se refere propriamente, assim, a uma ciência das humanidades, mas a uma tendência de um filosofar preso exclusivamente ao homem, ora o tomando como ser natural, ora como ser finito. Era preciso, segundo Foucault, que o "eu penso" fosse substituído, nas diversas "sínteses empíricas" (assinaladas pelas ciências humanas), pelo homem como ser finito, daí a noção de "sono antropológico" (FOUCAULT, 2002a, p. 351). Dessa forma, indaga Michel Foucault, "a filosofia não seria, no fundo, uma antropologia (FOUCAULT, "Philosophie et psychologie”, DE, I, 1994, p. 439)?"

Em outro lugar, "Philosophie et psychologie" (FOUCAULT, DE, I, 1994, p. 439), Foucault conceitua o termo: "Por antropologismo eu entendo essa estrutura propriamente filosófica que fez com que agora os problemas da filosofia sejam todos instalados no interior desse domínio que se pode chamar aquele da finitude humana". Inês Araújo assim interpreta essa importante idéia de Foucault: reduzir "o ser e o saber às nossas proporções humanas, ao nosso desejo de mesmice ou de nos assegurar uma identidade ou, ainda, nos convencermos de que há uma verdade do homem" (ARAÚJO, 2000, 
p. 430). Gros dirá também, próximo de Deleuze: até Kant o pensamento só era finito na medida em que estava alojado sob um fundo de infinito. A revolução antropológica se dá quando "a cultura moderna pode pensar o homem porque ela pensa o fim a partir dele mesmo" (GROS, 1997, p. 114).

Mas há um caráter foucaultiano positivo em relação a Kant. Este vai além de se colocar este pensador como o responsável por, após abrir o caminho para uma "reflexão sobre os limites da nossa razão" (FOUCAULT, "Préface à la transgression", DE, I, 1994, p. 239), reduzir "toda interrogação crítica a uma questão antropológica" (FOUCAULT, "Préface à la transgression", DE, I, 1994, p. 239), ou seja, àquilo que o homem pode e deve fazer. Um dos méritos de Kant foi, ao fazer uma filosofia da "afirmação não positiva", não buscar negar nada, existências ou valores, mas fazer uma "contestação" como "gesto que reconduz cada um deles aos seus limites" (DE, I, 1994, p. 238).

O Kant valorizado por Michel Foucault não será aquele das suas grandes obras, aquelas que comumente relacionaram o pensador com a questão da crítica. Nessa interpretação tradicional Alexandre Morujão, que assina o Prefácio da Crítica da razão pura (KANT, 1985, p. V), sugere que devamos inicialmente observar duas fases em Kant: a primeira é a pré-crítica, quando aparecem pequenas obras como "Os sonhos de um visionário explicados pelos sonhos da metafísica", de 1764, além do artigo "Sobre os primeiros princípios das diferenças das regiões no espaço", de 1768 . O anúncio da sua segunda fase, a crítica, situa-se a partir da pequena dissertação latina "De mundi sensibilis atque intelligibilis forma et principiis", de 1770. Como se constituiu doravante a "crítica" no conjunto mesmo da obra de Kant? 
Kant pretendera dar uma resposta à tradição científicofilosófica em vigor até sua época, desde a matemática de Descartes e Leibniz (deste chegando ao sistema de Wolf) à Física de Newton. Precisamente, a questões colocadas pelo racionalismo e empirismo, acerca da origem do conhecimento e da validade do saber. ${ }^{33} \mathrm{Ou}$ seja, como encontrar um fundamento para a verdade? Assim, são os sentidos ou a capacidade interna e inata do pensamento no sujeito que determinam aquilo que é real ou verdadeiro? Além disso, como o problema da moral pode ser resolvido, ou seja, o que o homem deve fazer, como agir e conseguir a felicidade? No balanço feito por Kant relativamente à Filosofia, a fase crítica deveria substituir a fase dogmática, do sistema de Leibniz e Wolff. Como Kant mesmo o disse,

A filosofia de Leibniz e de Wolf indicou uma perspectiva totalmente errada a todas as investigações acerca da natureza e origem dos nossos conhecimentos, considerando apenas puramente lógica a distinção entre o sensível e o intelectual, porquanto essa diferença é, manifestamente, transcendental e não se refere tãosó à sua forma clara ou obscura, mas à origem e conteúdo desses conhecimentos (KANT, 1985, p. 80).

33 "O que se contesta por alguns, como Lebrun, é a ideia defendida por Cohen segundo a qual Kant, com a sua crítica, "inauguraria os 'positivismos', restringindo a reflexão filosófica às condições de possibilidade das ciências e, no mesmo movimento, suprimindo, com a psicologia, a teologia e a cosmologia racionais, 'a metafísica'" (LEBRUN, 1993, p. 19). 
Além disso, a crítica deveria igualmente substituir a fase cética, ilustrada pelas ideias de Hume - que o tira do "sono dogmático" - como na defesa feita por ele de que não vemos empiricamente as causas e os efeitos, apenas vemos a sucessão de eventos: "O impulso de uma bola de bilhar é esperado com movimento na segunda. Eis tudo o que aparece aos sentidos externos" (HUME, 1989, p. 65). Assim, como resposta aos autores acima, quando Kant insere as análises relativas à "Lógica Transcendental" (segunda parte da sua Crítica da razão pura), é para poder operar uma síntese entre o empírico e o racional, mostrando a necessária relação que devem guardar tanto os pensamentos quanto os dados que obtemos através da sensibilidade: "Pensamentos sem conteúdo são vazios; intuições sem conceitos são cegas" (KANT, 1985, p. 89). ${ }^{34}$

No prefácio da segunda edição dessa crítica Kant mostra que "O destino não foi até hoje tão favorável que permitisse trilhar o caminho seguro da ciência à metafísica". A Lógica tivera êxito, mas tinha um caráter limitado, na medida em que se apegava somente à forma, não ao conteúdo daquilo que tratava. "Era a antecâmara das ciências" (KANT, 1985, p. 16). Por seu turno a Matemática e a Física trilharam um caminho exitoso, embora só a primeira tivesse determinado "seus objetos a priori, [...e] de modo inteiramente puro", enquanto que a segunda tivesse um percurso mais lento para compreender que a razão "tem que tomar a dianteira com princípios, que determinam os seus juízos segundo

34 Na Crítica da razão pura o elan vital ou "verdadeiro problema da razão pura" consistirá na resposta à pergunta: "como são possíveis os juízos sintéticos a priori?" (KANT, 1985, p. 49). 
leis constantes" (KANT, 1985, p. 18). Quanto à Metafísica, porém, tinha sido até então

[...] um conhecimento especulativo da razão completamente à parte e que se eleva inteiramente acima das lições da experiência, mediante simples conceitos (não como a matemática, aplicando os conceitos à intuição, devendo, portanto, a razão ser discípula de si própria (KANT, 1985, p. 18).

Nessa linha de pensamento Kant assinará suas obras de maior fôlego com nomes sui generis ligados à ideia de crítica: para responder aos limites da nossa razão caberá fazer uma Crítica da razão pura (1985); para responder a um entendimento possível acerca da moralidade, a Crítica da razão prática (1986) (além da Fundamentação da metafísica dos costumes, 1993); para investigar o sentimento de prazer ou desprazer até chegar aos juízos estéticos caberá realizar uma Crítica da faculdade do juízo (1995).

Diante desse percurso acima, que se refere ao criticismo kantiano, Foucault vai destacar algo ligado ao sentido de uma "afirmação não positiva" nascida com Kant e que se reveste, na sua forma filosófica e conceitual, como a emergência de um espaço transcendental. Afinal, Kant

[...] contorna a representação e o que nela é dado, para endereçar-se àquilo mesmo a partir do qual toda representação, seja ela qual for, pode ser dada [...]. Qualquer outra ligação, para ser universal, deve 
fundar-se para além de toda experiência, no a priori que a torna possível. Não que se trate de um outro mundo, mas das condições sob as quais pode existir qualquer representação do mundo em geral (FOUCAULT, 2002a, p. 254, grifo nosso). ${ }^{35}$

\begin{abstract}
A interpretação "positiva" do empreendimento filosófico de Kant feita por Foucault traz ainda outro ponto de extrema importância, na verdade surgindo como prolongamento daquela "afirmação não positiva"; a saber, a relação de Kant com algo chamado de "herança crítica". É o momento de abertura para a noção da crítica forte em Foucault que começa efetivamente e, como se disse mais atrás, não se valendo propriamente das grandes obras kantianas. A pergunta de Foucault é a seguinte: como podemos demarcar ou
\end{abstract}

35 A noção geral, defendida por Michel Foucault, de que um dos aspectos importantes da crítica kantiana é ser um "instrumento", foi defendida por autores como Lebrun e Deleuze. Gérard Lebrun, em Kant e o fim da metafísica, logo no início adverte a seus leitores: "A Crítica não tem, portanto, como tarefa munir-nos de convicções novas, mas sim fazer-nos colocar em questão o modo que tínhamos de ser convencidos. Ela não nos traz uma outra verdade; ela nos ensina a pensar de outra maneira" (LEBRUN, 1993, p. 5). A mesma linha é percorrida por Deleuze: em A filosofia crítica de Kant, fazendo uma comparação entre as críticas da razão pura e da razão prática kantianas, Deleuze nos lembra que, para este, o que está em jogo é a denúncia de um uso transcendente dessas razões. No primeiro caso, de uma "razão especulativa que pretende legislar sobre si mesma"; no segundo caso, de uma "razão prática que, em vez de legislar sobre si mesma, se deixa condicionar empiricamente" (DELEUZE, 1983, p. 43). Daí a pretensão kantiana ser, antes de tudo, programática: a razão deve ser juiz da razão, "tal é o princípio essencial do método dito transcendental. Este método propõe-se determinar: $1^{\circ} \mathrm{A}$ verdadeira natureza dos interesses ou dos fins da razão; $2^{\circ}$ Os meios de realizar estes interesses" (DELEUZE, 1983, p. 11). 
limitar conceitualmente algo como uma "atividade crítica do Ocidente"? Para ele, ela está disposta inicialmente entre dois pólos, que aqui devem ser investigados: a "alta empresa kantiana", primeiro, deslindada, sobretudo, a partir de um pequeno artigo de jornal assinado por Kant em torno da pergunta "o que é o Iluminismo?"; e "as pequenas atividades polêmico-profissionais", em segundo lugar (FOUCAULT, 1995, p. 1). Ao fim desse movimento restará ainda, segundo o próprio Michel Foucault, outra questão: antes da Idade Moderna não poderíamos nos deparar com "atitudes críticas" as mais diversas levadas a cabo por variados pensadores ou intelectuais dispersos na sociedade? Por que pretender iniciar esse movimento crítico com Kant?

Compreender de fato essas questões implica em se procurar penetrar em algumas sutilezas em torno da noção de crítica nesse autor, desta vez não reposicionando mais Kant diante do problema da "representação", central até o fim do século XVIII, e objeto de análise em Les mots, mas o tomando por foco na crítica utilizada para anunciar o "Iluminismo", abertura foucaultiana para a compreensão da tarefa da filosofia como "diagnóstico do presente". Mas que se chama a atenção aqui para o fato de que essas duas questões acima são oriundas de uma noção anterior, aclarada no texto foucaultiano de 19821983 - Le gouvernemente de si et des autres (FOUCAULT, 2008) - que aprofunda e complementa "Qu'est-ce que la critique? [Crítique y Aufklärung] e "Qu'est-ce-que les Lumières?" (DE, IV, 1984): a emergência da "modernidade".

Para além da referência a Kant na sua tese complementar de doutorado, onde o texto kantiano Anthropologie du point de vue pragmatique é traduzido para o francês, o curso proferido 
por Foucault no Collège de France: Le gouvernemente de si et des autres (FOUCAULT, 2008) - é bastante esclarecedor, e se inicia tomando por base uma investigação precisa e desconcertante à primeira vista: a filosofia como discurso da modernidade tem seu início com Kant.

Esta ideia parece se contrastar com algumas posições bastante recorrentes na literatura filosófica sobre o tema. Habermas, no livro O discurso filosófico da modernidade (1990), identifica em Hegel "o primeiro filósofo a desenvolver um conceito preciso de modernidade"; e aponta Hegel como aquele que busca estabelecer uma "relação interna entre modernidade [Modernität] e racionalidade, tida como evidente até Max Weber e hoje posta em questão" (HABERMAS, 1990, p. 16).

Hegel, segundo Habermas, faz uma distinção entre o mundo antigo e o mundo novo ou mundo moderno, distinguidos porque aí há uma abertura para o futuro. Nesse sentido, o mundo moderno gozará de uma "posição de destaque" frente à história, vista na sua totalidade, uma vez que ele representará o novo, gerado "a partir de si", e porque, compreendido como "atualidade da época mais recente, tem de assumir, como uma renovação contínua, a cisão que esses novos tempos levaram a cabo com o passado" (HABERMAS, 1990, p. 18). No início do Capítulo IV da sua Filosofia da História Hegel expressa isso, esse "tempo moderno", como o "período do espírito consciente de sua liberdade, ao querer a verdade e a eternidade em si e por si universal" (HEGEL, 1995, p. 342).

Para Hyppolite, uma das razões de se buscar demarcar o antigo do moderno em Hegel foi a necessidade de superar a aparente "separação" entre o individualismo dos novos 
tempos e o Estado, contradição, pois, entre a vontade particular e a vontade geral, esta última representada pelas demandas estatais, alcançadas muitas vezes por meio de "coação". Ora, interpreta Hyppolite, a questão hegeliana estava em ver que, diferentemente do mundo antigo, quando os dois lados acima se estabeleciam sem mediações, os novos tempos vão exigir alguma mediação entre aquelas vontades, sempre tendo a liberdade como prerrogativa, uma vez que o Estado "é a razão na terra" e, portanto, não tem nada em si mesmo de “artificial” (HYPPOLITE, 1971, p. 93-94). ${ }^{36}$

Herbert Marcuse, em Razão e Revolução, também aborda a questão da modernidade e da história em Hegel a partir de um delineamento geral da sua filosofia. $\mathrm{O}$ tempo aparece na obra hegeliana porque, se o "verdadeiro ser é a ideia", esta necessita se desenvolver no espaço (como natureza), mas também no tempo, como espírito (MARCUSE, 1978, p. 207). Os novos tempos, não obstante, encerram o movimento histórico: tendo em vista que "Hegel achava que a história havia atingido sua meta, e que ideia e realidade haviam encontrado um fundamento comum", a sua obra "marca, pois, o apogeu e o fim da historiografia filosófica crítica" (MARCUSE, 1978, p. 209).

O problema da modernidade para Foucault se coloca, porém, de uma forma diferente. Para ele é verdade que na cultura européia a modernidade já tinha aparecido pelo

36 Essa importância do Estado em Hegel é lembrado por Konder (1991, p. 80-82), uma vez que, dentro dos períodos da história da filosofia demarcados por Hegel: de Tales a Plontino, deste a Descartes e de Descartes até o idealismo alemão - ou mesmo no palco da história mundial a presença do Estado é "o que conta", ou seja, através do Estado se dá o "coroamento da eticidade". 
menos desde o século XVII ao início do XVIII. Aparecera, contudo, sob um "eixo longitudinal", sempre numa perspectiva de polaridade entre algo que seria antigo e algo moderno, e em torno de duas perguntas: "qual autoridade aceitar? Qual modelo seguir?" (FOUCAULT, 2008, p. 15).

Com Kant esse eixo se verticaliza, e a tarefa genealógica consistirá em compreender não "a noção de modernidade, mas da modernidade como questão" (FOUCAULT, 2008, p. 15, grifo nosso). Para Foucault, a novidade do texto kantiano é justamente esta: ao falar sobre a história, Kant não o faz tomando por base uma questão de origem (como quem pergunta sobre as origens da história humana); e não vai colocar uma questão de acabamento (achèvement) como realização (accomplissement), ou como finalidade. A novidade do texto de Kant reside, primeiro, em pôr uma questão sobre o presente ou atualidade que, se já tínhamos encontrado isso explicitamente em autores, como Descartes ou Leibniz, não o fora no sentido da pergunta: "O que é precisamente o presente ao qual pertenço?"; segundo, não havia neles também a questão: qual o "elemento do presente que se trata de reconhecer, de distinguir, de decifrar entre todos os outros?".

O caso de Descartes é exemplar e elucidativo. Como apontou Paulo Vaz, é verdade que certa ideia de presente em Descartes pode ser encontrada, por exemplo, em obras como discurso do método. Dentro do estilo filosófico-biográfico desta obra, René Descartes faz um balanço da sua vida, concluindo logo no início que, apesar de ter sido "nutrido nas letras desde a infância", achou-se ao final "enleado em tantas dúvidas e erros, que me parecia não haver obtido outro proveito, procurando instruir-me, senão o de ter descoberto cada vez mais 
a minha ignorância". Diante dessa retrospectiva da sua vida e da sua época daí ele vislumbrar a necessidade de um novo caminho para a filosofia (DESCARTES, 1979, p. 30).

Paulo Vaz chama a atenção, porém, para o fato de que em Descartes isso não significou "um meio para a filosofia problematizar sua própria atualidade discursiva: ele mantém a autonomia dos problemas filosóficos face ao presente" e ela, a filosofia, não sai da perspectiva de buscar um "discurso do universal" (VAZ, 1992, p. 44); além disso, o "'Eu' que interroga pode ser qualquer um, em qualquer momento e lugar" (VAZ, 1992, p. 45). O caso de Kant é diverso disso. Ele mostra que aquele que fala entende-se como fazendo parte, ele mesmo, desse processo.

Essa é a linha de entendimento de Michel Foucault. Para este, pondo a "modernidade como questão" a partir de Kant vão ser fundadas duas tradições filosóficas: a primeira é uma "tradição da filosofia crítica que põe a questão das condições sob as quais um conhecimento verdadeiro é possível" (FOUCAULT, 2008, p. 21). Kant fez nascer a partir do século XIX toda uma pesquisa sobre uma analítica da verdade, encampada pela filosofia anglo-saxônica. A segunda tradição da abordagem crítica será aquela que fará a pergunta: qual é o campo das nossas experiências atuais ou o "campo atual das experiências possíveis" (FOUCAULT, 2008, p. 22)? Com Kant, para Foucault, "uma das grandes funções da filosofia dita moderna" torna-se aquela que busca se "interrogar sobre sua própria atualidade" (FOUCAULT, 2008, p. 16). Essa segunda vertente da crítica aportará naquilo que Foucault chama de ontologia do presente, da atualidade, da modernidade ou ontologia de nós mesmos (são expressões similares). 
Enfim, a partir de Kant surgem essas duas formas de crítica, Foucault mesmo sendo optante pela segunda, que se estende de Hegel à Escola de Frankfurt, passando por autores como Nietzsche ou Weber. ${ }^{37}$ E optando por isso será mais interessante para ele empreender uma pesquisa sobre a atualidade do que sobre a verdade de um discurso. Kant ainda vem como auxilio a isso, a partir de uma noção mais forte de crítica, que se acrescenta e se sobrepõe à noção "arqueológica", e que nasce a partir das suas reflexões sobre a Aufklärung.

A tese de Foucault, ao abordar o Iluminismo, interpretando Kant, deixa de lado a peculiaridade do período histórico em causa, colocando fundamentalmente duas ideias: Kant é o primeiro a unir de forma "estreita" e "interior" a significação da sua obra com relação ao conhecimento, uma reflexão sobre a história e uma compreensão do momento em que ele escreve. Refletir sobre seu tempo: verdadeiramente, a primeira empreitada filosófica nesse sentido -, observando-se que Kant o fará de uma "maneira quase inteiramente negativa": a Aufklärung será uma espécie de "saída" de um estado de minoridade para um estado de luz, da "diferença" entre os dois momentos, por querer inaugurar toda uma nova relação entre vontade, autoridade e o uso da racionalidade.

O texto-referência dessa Crítica forte em Kant aparece para Foucault na polêmica em torno do Iluminismo deflagrada entre Kant e Moses Mendelssohn. Mendelssohn fora um conhecido filósofo alemão do século XVIII, que tenta

37 Não se pode esquecer das palavras de Foucault ao falar dos seus predecessores: "todo o meu futuro filosófico foi determinado por minha leitura de Heidegger", embora Nietzsche tenha "predominado" (FOUCAULT, "Le retour de la morale", DE, IV, 1994, p. 703). 
responder à pergunta "o que é o Iluminismo?" no jornal "Berlinische Monatsschrift", em nove de setembro de 1784. Em doze de dezembro do mesmo ano Kant vai deter-se acerca da mesma pergunta, sem saber da anterior resposta do autor acima, e com uma genialidade e sensibilidade para apreender o seu momento histórico peculiar.

Esclarecimento se caracteriza, escreve Kant, pela "saída do homem da sua menoridade", menoridade como sendo a "incapacidade de fazer uso do seu entendimento sem a direção de outro indivíduo". Foucault aponta a novidade kantiana: diferentemente do que acontecia antes, essa saída não indicava "a idade do mundo no qual a gente se encontra atualmente, uma certa idade do mundo que seria distinta das outras por algum caráter próprio [... ou] separado por um certo acontecimento dramático"; segundo, o momento presente designado como acontecimento mais ou menos iminente; terceiro, o momento presente definido como momento de transição (FOUCAULT, 2008, p. 26).

A "saída" em Kant tem outro sentido. Primeiro, ela não aponta para nada, para nenhum porvir específico; segundo, ela não menciona se é algo ativo ou passivo: "'saída do homem'" - diz simplesmente o texto. Em terceiro lugar, não é um discurso de descrição o que se verifica, mas de prescrição: "Tenha a coragem de se servir do seu próprio entendimento" (FOUCAULT, 2008, p. 27) - coragem a ser contraposta à "letargia" e à "covardia":

Se tenho um livro que faz as vezes de meu entendimento, um diretor espiritual que por mim tem consciência, um médico que por mim decide a respeito de minha dieta, 
etc., então não preciso de esforçar-me eu mesmo. Não tenho necessidade de pensar, quando posso simplesmente pagar (KANT, 2005, p. 64).

Kant divisa as dificuldades de se sair desse estado de menoridade, haja vista em muitos já ser isso quase que uma "natureza" neles. Quer dizer, "grilhões" que os prendem sob o nome de "preceitos" ou de "fórmulas" prontas. Sair desse estado de preguiça, tendo a coragem para realizar tal deslocamento é sempre algo difícil e tarefa para poucos, mas - e aí está a novidade dos novos tempos (os de Kant) - possibilidade mais fácil quando "se vive em uma época de esclarecimento" (KANT, 2005, p. 64).

Há muitos elementos aqui para a análise. Foucault realça logo que a menoridade não é uma impotência natural humana, uma espécie de "infância da humanidade" (FOUCAULT, 2008, p. 28); não é uma noção política ou jurídico-política, como alguém que esteja privado do exercício de seus direitos; não é também uma questão de autoridade, como a que foi aludido acima (o livro, o diretor espiritual ou o médico). A condição de maioridade não emerge igualmente como que de um átimo, por exemplo quando uma revolução qualquer tem a possibilidade de destronar um despotismo autocrático ou opressões outras, porque muito naturalmente o então novo regime que sobe ao poder continuará à sua maneira perpetuando formas opressoras.

Ora, o esclarecimento de um povo só pode ser alcançado lentamente. E essa lentidão não é nada mais do que a instalação de um processo ou estado permanente de liberdade. 
Precisamente, liberdade para saber redistribuir a relação entre o governo de si e o governo dos outros (FOUCAULT, 2008, p. 31), utilizando-se da própria razão como guia; liberdade para "fazer um uso público de sua razão em todas as questões" (KANT, 2005, p. 65). Foucault tenta aprofundar no seu curso o sentido de público e de privado. O Publikum de Kant é compreendido como dotado de uma

[...] relação concreta, institucional ou instituída em todo caso, entre o escritor [o escritor qualificado, savant em Francês ou Gelether em alemão, como homem de cultura] e depois o leitor (o leitor considerado como indivíduo, qualquer um) (FOUCAULT, 2008, p. 09).

Em Kant o uso particular ou "privado" é aquele "que uma pessoa pode dele fazer num cargo civil qualquer que ocupe". Por exemplo, como empregado de uma empresa, professor de uma congregação, sacerdote etc., onde se exige obediência a regras e normas; onde se age por procuração e não se é livre. Mas, por outro lado, pode-se exercer a liberdade quem se pusesse a usar a razão publicamente - essa razão goza de uma "liberdade ilimitada" -, quer dizer, pondo-se a escrever de forma pessoal ao "público leitor" acerca dos frutos do seu estudo e reflexão. Franquear essa condição é importantíssimo, e poder-se-ia tomar como referência governos como o de Frederico, o Grande (KANT, 2005, p. 70).

Em outro lugar pode-se perceber que a distinção entre os usos público e privado da razão em Kant, segundo a interpretação de Foucault, consiste em operar entre eles uma 
“superposição". A racionalidade deve primar para que se faça um uso livre e público ao mesmo tempo, tanto não sendo obediência cega e irrefletida, quanto não se pondo sob o império de uma vontade sem arestas. Daí tal questão ser levada ao âmbito político, podendo tal obediência ser assegurada através do "contrato do despotismo racional com a livre razão", quer dizer, um governo que também ele se curve aos princípios da "razão universal" (FOUCAULT, "Qu'est-ce que les Lumières?”, DE, IV, 1994, p. 567).

Uma primeira conclusão de Michel Foucault é a de que essa saída da menoridade termina não sendo muito clara em Kant. Os paradoxos e dificuldades iniciais são: a passagem da descrição para a prescrição, o entendimento acerca de quem é aquele homem que deve sair, e em que consiste aquela saída. Foucault mostra a ambigüidade presente em toda essa empreitada "iluminista", haja vista a "saída" da menoridade consistir ora como um "fato" que está transcorrendo, ora como uma “tarefa e obrigação” de cada um (FOUCAULT, “Qu'est-ce que les Lumières?”, DE, IV, 1994, p. 568, 563-564).

Essas ponderações feitas por Foucault buscaram realçar as lacunas ou o horizonte aberto a partir de Kant, muito mais do que a existência de algum preceito fixo. Nesse horizonte cabe destacar que é com Kant que se eleva a ideia segundo a qual o papel geral da filosofia é buscar fazer um "diagnóstico" do tempo presente, papel este que foi desenvolvido proximamente pela corrente estruturalista nos anos de 1960, como se abordou no primeiro Capítulo desta tese. Mas a perspectiva crítica foucaultiana vai além disso, guardando suas peculiaridades. 
Ora, a questão do diagnóstico ressoa porque se a compreensão foucaultiana é de que "sair da menoridade e exercer a atividade crítica são, creio, duas operações que estão ligadas", houve vários elementos inconclusos ou hiatos teóricos deixados pelo texto de Kant, abrindo caminho para a constituição de um saber crítico foucaultiano, reforçando a idéia da crítica como organon. Com isso, a Aufklärung se torna tanto um "acontecimento singular inaugurando a modernidade européia" quanto um "processo permanente que se manifesta" na história da razão, que aponta para um seu desenvolvimento singular e para o nascimento de formas de racionalidade e técnica ocidentais (FOUCAULT, 2008, p. 21).

A necessidade do "diagnóstico" se impõe para Foucault porque a humanidade não se tornou "maior" a partir da "idade das luzes"; ao contrário disso, se se empreende de fato aquele êthos crítico cabe insistir no questionamento acerca dos "limites que nos colocaram" e da forma de sua transposição possível. Ora, a presença de Kant evidencia-se aí na medida em que Michel Foucault está diante da pergunta acerca do seu momento histórico (ou herança histórico-filosófica); na medida em que está atento à melhor forma de pensar, sentir, agir e se conduzir, tal como o fez Kant; na medida em que interessa a ele não cair - como aconteceu, porém, com este em ambigüidades.

Diagnosticar o seu tempo, em Foucault, significa não cair em certas armadilhas. No plano filosófico pode-se destacar o perigo em não resvalar para uma filosofia da consciência, próxima da fenomenologia e do existencialismo, de um marxismo "sumário" ou de uma desvalorização de propostas de novas 
correntes, como o estruturalismo. ${ }^{38}$ Daí o "diagnóstico" ser conceituado por Foucault já em 1967, na entrevista "Qui êtesvous professeur Foucault" (DE, I, 1994, p. 606), como "dizer o que somos hoje e o que significa, hoje, dizer o que dizemos". Uma tarefa desenvolvida por Michel Foucault através de suas análises do passado, ou seja, "no fundo, apresentar uma crítica de nosso tempo, fundada sobre análises retrospectivas" (FOUCAULT, "Conversation avec Michel Foucault", DE, I, 2001, p. 1051).

Essas análises deveriam fazer aparecer o "inconsciente cultural" aí presente (FOUCAULT, "Conversation avec Michel Foucault", DE, I, 2001, p. 1057), dentro das práticas dos sistemas de exclusão dos quais todos fazem parte, entendendo que Para Michel Foucault nossa sociedade buscou menos exilar, primeiro, ou assassinar, torturar e purificar, como segunda característica maior, do que excluir (FOUCAULT, "Je perçois l'intolérable", DE, I 2001, p. 1071). Daí ser preciso "pôr em jogo, exibir, transformar e reverter os sistemas que nos ordenam passivamente", tarefa que buscou empreender nos seus estudos críticos (FOUCAULT, "Conversation avec Michel Foucault", DE, I, 2001, p. 1061).

Como queria Habermas, na interpretação de Rouanet, o suposto aparecimento de uma tendência crítica em Foucault só transparece sob o fundo de uma rejeição da "modernidade social, e pós-moderno, porque rejeita a modernidade cultural"

38 O objetivo na presente tese é adentrar no plano conceitual da crítica, e não iniciar um debate acerca das posições filosóficas adotadas por Foucault relativamente àquelas correntes, discussão que encontra amplo material nos volumes dos Dits et écrits, desde os anos de 1960 até os anos de 1984. 
(ROUANET, 1987, p. 219)? Essa crítica foucaultiana às avessas desemboca no questionamento da ideia de humanismo e a de ciência. Quanto ao primeiro aspecto, para Sergio Paulo Rouanet não se tratava em Foucault de contestar o humanismo pura e simplesmente, mas a sua "filantropia" (ROUANET, 1987, p. 219). Quer dizer, uma noção por demais idealista e pacífica de se ver iniciativas referendadas como algo com um valor ou crédito ao humano, sem contar com as estratégias escondidas nesse meio. Em suma, se Foucault duvida de que a "reforma das instituições asilares por Pinel ou das instituições carcerárias pelos seguidores de Bentham seja atribuível ao humanitarismo do século das Luzes", isso não é o bastante para acreditar que "as credenciais de modernidade só possam ser outorgadas a quem acreditar na bondade natural dos reformadores iluministas" (ROUANET, 1987, p. 219).

Na verdade, o humanismo é criticado por Michel Foucault tanto por aquilo que ele esconde, dentro das estratégias sociais do poder, quanto por estar bastante atrelado a uma noção rejeitada de sujeito:

O humanismo foi que inventou alternadamente essas soberanias assujeitadas que são a alma (soberania sobre o corpo, submetida a Deus), a consciência (soberania na ordem do julgamento; submissa à ordem da verdade), o indivíduo (soberania titular de seus direitos, submetida às leis da natureza ou às regras da sociedade), a liberdade fundamental (interiormente soberana, exteriormente consentante e accordée à seu destino) (FOUCAULT, "Par-delà le bien et le mal", DE, I, 2001, p. 1094). 
Após com o Direito romano o Ocidente criou essa outra "armadura", que foi a "individualidade como soberania submissa":

[...] o humanismo consiste em querer mudar o sistema ideológico sem tocar na instituição; o reformista busca a instituição sem tocar no sistema ideológico. A ação revolucionária se define, ao contrário, como um abalo simultâneo da consciência e da instituição; o que supõe que se ataque as relações de poder das quais elas são o insturmento, a armadura (FOUCAULT, "Par-delà le bien et le mal", DE, I, 2001, p. 1099).

Um conhecimento por diagnóstico não deve estar restrito em Foucault a análises sociais ou políticas. Sua característica é "definir" e "determinar diferenças". Um exemplo elucidativo disso foi o diagnóstico feito por Saussure ao definir o que era a língua e o que era a palavra, ou quando diferenciou sincronia de diacronia (FOUCAULT, "Les problèmes de la culture. Um débat Foucault-Preti”, DE, I, 2001, 1237-1238). Pensando assim, os seus estudos sempre se detiveram na tentativa de "resolver uma demanda imediata": a loucura, em um momento (quer dizer, quando a "categoria de doença mental" começa a surgir); o sistema penal, em outro etc. (FOUCAULT, “Le pouvoir, une bête magnifique", DE, III, 1994, p. 377).

Os propósitos foucaultianos não foram no sentido de conduzir um discurso verdadeiro sobre o que quer que fosse; fazer uma história "verdadeira ou falsa, válida ou não, pouco importa" - diz ele a propósito da sua histoire de la folie. O 
importante mesmo ou, em suas palavras, "meu verdadeiro problema, no fundo, é forjar instrumentos de análise, de ação política e de intervenção política sobre a realidade que nos é contemporânea e sobre nós mesmos" (FOUCAULT, "Pouvoir et savoir", DE, III, 1994, p. 414).

Foucault busca, portanto, os "acontecimentos", e não raros aqueles de fundamentais no quadro da existência humana: “qual é o acontecimento sob o signo do qual nós nascemos, e qual é o acontecimento que continua ainda a nos atravessar" (FOUCAULT, "La scène de la philosophie", DE, III, 1994, p. 574)? Detendo-se no horizonte da sociedade capitalista e industrial em formação o "primeiro espaço que me parece colocar o problema e manifestar justamente essa diferenciação social e histórica forte das sociedades é o espaço de exclusão, de exclusão e de enclausuramento (FOUCAULT, "La scène de la philosophie", DE, III, 1994, p. 577).

\section{Certo devir da governamentalidade e a epistemologia}

Em "Crítica y Aufklärung" (FOUCAULT, 1995, p. 5) ressurge o tema da governamentalidade, atrelado ao papel a ser feito do empreendimento crítico. É imprescindível uma referência aqui a esta relação. A governamentalidade é um conceito que aparece na obra foucaultiana com o seu curso no Collège de France Sécurité, territoire, population (2004) e com Naissance de la biopolitique (2004b), termo que surge com um sentido largo, não apenas se referindo ao século XVI e, aí, às suas estruturas políticas e à gestão do Estado, mas a algo que se formou no século XVIII: toda uma racionalidade que encontrou no funcionamento do Estado o seu campo de aplicação, 
e que vai relacionar a série segurança-população-governo (FOUCAULT, “la 'gouvernementalité'”, DE, III, 1994, p. 635).

Essa noção surgiu para permitir a Foucault escapar de uma concepção jurídica do sujeito, permitindo "fazer valer a liberdade do sujeito e a relação aos outros, ou seja, o que constitui a matéria mesma da ética" (FOUCAULT, "L'éthique du souci de soi comme pratique de la liberté", DE, IV, 1994, p. 729). Mas a utilização desse conceito ganhou larga utilização, pois com ele foi possível estender o tema da governamentalidade para toda a obra foucaultiana. Por exemplo, em "Le souci de la vérité" (FOUCAULT, DE, IV, 1994, p. 670) ele disse que, ao estudar a loucura, "tratava-se em suma de saber como se 'governava' os loucos" e, com o segundo volume de histoire de la sexualité, de como se governar a si mesmo, embora governar-se a si e aos outros estivesse sempre ligado ao horizonte geral da "experiência" das pessoas.

O gouvernement vai se relacionar a uma história da atitude crítica, na medida em que será buscado o seu reverso: afinal, como não ser governado? No texto acima referido (Foucault, 1995) diz Michel Foucault que a "indocilidade reflexiva" ou a "não servidão voluntária" - aquilo que caracterizará a crítica doravante - esteve atrelada a três momentos decisivos: o retorno à leitura das escrituras, contra as imposições do poder eclesiástico (esfera da religião); a recusa em aceitar leis injustas (questão do direito natural); e, finalmente, ser crítico foi "não aceitar como verdade "o que uma autoridade disse que é a verdade" (terreno da ciência) (FOUCAULT, 1995, p. 4).

É preciso entender que Foucault tinha em vista aqui uma visão do próprio percurso da razão no Ocidente, de cuja herança se deve ter ciência nos tempos atuais. Assim, houve 
uma razão analítica (séc. XVIII), com sua relação à natureza; uma razão dialética (séc. XIX), com sua relação à existência (indivíduo e sociedade, consciência histórica, sentido e não sentido, vivente e inerte), enquanto que hoje se trata de "saber quais são as condições impostas a um sujeito qualquer para que ele possa se introduzir, funcionar, servir de ligação na rede sistemática daquilo que nos rodeia" (FOUCAULT, "Foucault, le philosophe, est en train de parlez. Pensez", DE, I, 2001, p. 1292).

De início ele realça que o tema da governamentalidade foi "introduzido no Ocidente pelo Cristianismo", tendo em vista que na Antiguidade não é encontrado um poder "individualizante" de tal monta: um soberano-pastor, cuidando das suas "ovelhas". Resgatar, portanto, o sentido foucaultiano da pastoral cristã é fundamental para o entendimento da governamentalidade, bem como para começar a entender o horror foucaultiano por práticas que buscam enquadrar o indivíduo em certos esquemas aprisionantes.

A pastoral cristã ${ }^{39}$ buscava o governo das almas, quer dizer, um procedimento técnico onde está em causa certa

[...] direção de consciência, o cuidado das almas, a cura das almas, todas essas práticas que vão do exame à confissão, passando pelo consentimento, essa relação imposta de si mesmo a si mesmo em termo de verdade e de discurso imposto, é isso, parece-me, que é um dos pontos

39 Esse tema aqui é apenas introduzido, pois voltará a ser abordado no Capítulo IV desta tese. 
fundamentais do poder pastoral e que faz dela um poder individualisante (FOUCAULT, "La société disciplinaire en crise, DE, III, 1994, p. 549).

Ora, nesse poder estabelecido entre o pastor e sua ovelha a mudança está justamente na passagem entre o domínio de um território, que dá lugar a um domínio sobre a multiplicidade de indivíduos (“Sexualité et pouvoir", DE, III, 1994, p. 561). Nessas técnicas estão incluídos o conhecimento da verdade bíblica, o seu ensino, como também um conhecimento acerca "do que se passa na alma, no coração, ao mais profundo dos segredos do indivíduo". Daí a importância da confissão, sendo "a produção da verdade interior, a produção da verdade subjetiva um elemento fundamental no exercício do pastor" ("La société disciplinaire en crise", DE, III, 1994, p. 564). Então, as técnicas cristãs podem ser resumidas como constituição de uma subjetividade através da técnica da interiorização, da tomada de consciência, do despertar de si sobre si mesmo (FOUCAULT, “La société disciplinaire en crise", DE, III, 1994, p. 566).

No texto "Qu'est-ce quela critique? [Crítique y Aufklärung]" Foucault aborda a polêmica instaurada no terreno da crítica acerca de como entender a Escritura. Isso implicou em se pensar e em se ensinar outras relações do homem com Deus, pautado numa volta efetiva à Bíblia:

Em uma época em que o governo dos homens era essencialmente uma arte espiritual - ou uma prática essencialmente religiosa ligada à autoridade de uma igreja, ao magistério de uma escritura não querer ser governado de tal modo era essencialmente buscar nas Escrituras 
uma relação distinta a que estava ligado o funcionamento do ensino de Deus. Não querer ser governado de tal modo era uma certa maneira de rechaçar, recusar ou limitar (diga-se como quiser) o magistério eclesiástico; era o retorno da Escritura; era a questão relativa ao autêntico da Escritura, o que tinha sido efetivamente escrito na Escritura (1995, p. 04).

Em "Du gouvernement des vivants" (DE, IV, 1994, p. 125126) Foucault aponta que, usando o termo governo no "sentido largo de técnicas e procedimentos destinados a dirigir a conduta dos homens" estudou, no interior deste tema, "o problema do exame de consciência e da confissão". Tal governo não sinaliza apenas para sujeitos que devem obedecer, mas também "manifestar, enunciando o que se é" (grifo nosso). O sujeito deve manifestar e aderir a uma verdade, implicando isso numa "obrigação de manter suas crenças, de aceitar a autoridade que os autentifica, fazendo eventualmente profession pública". Foucault mostra que durante as práticas penitenciais dos séculos II ao V não havia a "forma de uma confissão verbal analítica das diferentes faltas com suas circunstâncias" (FOUCAULT, "Du gouvernement des vivants", DE, IV, 1994, p. 126-127), havendo a "verbalização da confissão dos pecados" só mais tarde, "de início com a prática da penitencia tarifada, depois a partir dos séculos XII e XIII, quando será organizado o sacramento de penitência". Um parágrafo longo sintetiza o que foi dito:

A obediência incondicional, o exame ininterrupto e a confissão exaustiva foram, pois, um conjunto no qual cada elemento implica os dois outros. A manifestação verbal da verdade que se cachê ao vernement 
dos homens uns pelos outros, tal que El agtenha mis en oeuvre dans as instituições monásticas - e sobretudo cénobitiques - a partir do século IV. Mas é preciso sublinhar que essa manifestação não tem por fim estabelecer o domínio soberano de si sobre si; o que se attend, ao contrário, é a humilité e a mortificação, o detachement a l'égard de si e a constituição de uma relação a si que tende à destruição da forma do si (FOUCAULT, "Du gouvernement des vivants", DE, IV, 1994, p. 129)

Ou seja, enquanto que o Estado se mostra como um poder centralizado e centralizador, a pastoral é um poder individualizador: vindo com os Hebreus, Deus aparece como o pastor dos homens, suas ovelhas, preocupado menos com a terra do que com o rebanho. Além disso, no seu papel de agrupar, guiar e conduzir o seu rebanho; de assegurar a sua saúde e o seu bem, a questão era benevolência constante, individualisada e final ("'Omnes et singulatim'"): vers une critique de la raison politique", DE, IV, 1994, p. 136-139).

A tecnologia pastoral é uma tecnologia do poder que vela pela vida e pelos atos dos indivíduos "em seus mais ínfimos detalhes", através de uma atitude de "submissão"; como sintetiza Foucault, "A obediência é uma virtude" (FOUCAULT, "'Omnes et singulatim'": vers une critique de la raison politi-

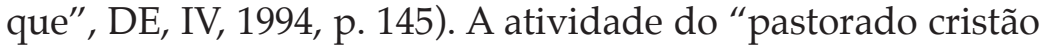
supõe uma forma de conhecimento particular entre o pastor e cada uma de suas ovelhas". Para tanto, o "pastor deve ser informado das necessidades materiais de cada membro do rebanho [...], ele deve saber o que se passa na alma de cada 
um deles, conhecer seus pecados secretos, seu progresso sobre a via da santidade". Para isso ele vai utilizar o exame de consciência e a direção da consciência. Esta se relaciona com o deixar-se conduzir a cada instante pelo pastor; aquela, um momento de abertura inteira ao seu diretor, revelando todo aquilo que há nas "profundezas da alma" (FOUCAULT, "'Omnes et singulatim"”: vers une critique de la raison politique", DE, IV, 1994, p. 147).

Em comparação com a civilização grego-romana o Ocidente cria um "estranho" liame entre "obediência total, o conhecimento de si e a confissão às pessoas". É preciso mortificar-se, não como sacrifício pela cidade, mas como morte numa relação de si a si, jogo cujas peças são "a vida, a morte, a verdade, a obediência, os indivíduos, a identidade" (FOUCAULT, "'Omnes et singulatim'": vers une critique de la raison politique", DE, IV, 1994, p. 147). Como Foucault o explica:

Nossa civilização desenvolveu um sistema de saber o mais complexo, as estruturas de poder as mais sofisticadas: o que fez de nós essa forma de conhecimento, esse tipo de poder? De qual maneira essas experiências fundamentais da loucura, do sofrimento, da morte, do crime, do desejo e da individualidade estão ligadas, mesmo se os não temos delas consciência, o conhecimento e o poder? Eu estou certo de nunca encontrar a resposta; mas isso não que dizer que nós devemos renunciar a colocar a questão (FOUCAULT, "'Omnes et singulatim'": vers une critique de la raison politique", DE, IV, 1994, p. 148). 
Caudatário do movimento pastoral cristão aparece a "disseminação dessa arte de governar em domínios variados, tais como governar as crianças, os pobres e os mendigos, uma família, uma casa, os exércitos, as cidades, os Estados, seu próprio corpo, seu próprio espírito", com suas recusas (FOUCAULT, 1995, p. 3), em segundo lugar; e um terceiro momento, aquele em que Foucault se refere ao 'não querer ser governado' como "não aceitar como verdade o que uma autoridade disse que é verdade" (1995, p. 4).

Quanto ao segundo momento, Foucault diz que da metade do século XVI ao fim do XVIII se desenvolve algo que não será mais relacionado com conselhos ao príncipe e nem como ciência da política, mas uma arte de governar, enumerando em "La 'governamentalité'" (FOUCAULT, DE, III, 1994, p. 635) suas características: se antes havia descontinuidade na "doutrina do príncipe" ou na "teoria jurídica do soberano" entre o governo de si pela moral, o governo da família e o governo do Estado, a arte de governar implicará em uma "continuidade ascendente e descendente": ascendente: para se governar um Estado é preciso governar a si e a sua família; descendente: cabe ao Estado poder governar aquilo que se passa com as pessoas e com as famílias. Surge a polícia. Assim, "como introduzir essa atenção, essa meticulosidade, esse tipo de relação do pai de família a sua família no interior da gestão de um Estado?" (FOUCAULT, “La 'governamentalité'”, DE, III, 1994, p. 641-642).

Outra característica é a "A introdução da economia no interior do exercício político, é isso, creio, que será a aposta essencial do governo" (FOUCAULT, “La 'governamentalité'”, DE, III, 1994, p. 642), mas uma economia voltada para a sua 
expressão mais geral, ou seja, para o "estado inteiro", o que inclui a gerência sobre os habitantes, as riquezas, as condutas das pessoas então vigiadas, de um "controle não menos atento que aquele do pai de família sobre a ocupação doméstica e seus bens" (FOUCAULT, "La 'governamentalité'”, DE, III, 1994, p. 642). Daí a diferenciação conceitual de Foucault: uma economia que no século XVI era entendida como forma de governo (Maquiavel e a dupla posição do poder, diante do território e dos seus habitantes o ilustra) e, já no século XVIII, "um nível de realidade, um campo de intervenção", (o contraste observado com La Perrière, para quem se governa as coisas na sua relação com os homens) (FOUCAULT, "La 'governamentalité'”, DE, III, 1994, p. 643).

Se a ciência econômica vai ser importante é no sentido de que ela girará em torno do território, da riqueza e da população, sabendo-se que esta pode ser objeto de intervenção; nas palavras de Foucault: "artificialmente modificada" (FOUCAULT, “Sécurité, territoire et population”, DE, I, 1994, p. 721-722) - fazendo "a passagem de uma arte de governar para uma ciência política" e se tornando a economia política tanto uma ciência quanto uma técnica de intervenção do governo (FOUCAULT, “La 'governamentalité'”, DE, III, 1994, p. 653 e 655).

Surge, na segunda metade do século XVIII, a bio-política, ligada a aspectos como higiene pública e medicina social ("Sécurité, territoire et population", DE, I, 1994, p. 723). Foucault faz observar que a profissionalização do médico se fez sobre o "fundo de uma "política de saúde"” (FOUCAULT, "La politique de la santé au XVIII siècle", DE, III, 1994, p. 726-727), incorporando temas como assistência, atenção às 
crianças e família, higiene e medicina como controle social (que poderá intervir no social), a pobreza, a doença e os imperativos do trabalho e da produção, o bem público como finalidade do rei legítimo, conseguida não pelo saber do governo em relação a leis e costumes, mas fruto de uma "técnica de gestão, aplicada a domínios particulares" (FOUCAULT, "La politique de la santé au XVIII siècle", DE, III, 1994, p. 729);

Depois vem a circularidade da governamentalidade: o seu fim, como proposta de se alcançar um bem comum, não é "finalmente nada mais do que a submissão absoluta"; sendo o "bem" a obediência à lei, obedecendo-se a ela se chega à soberania (FOUCAULT, "La 'governamentalité'”, DE, III, 1994, p. 645). Mas não se trata de uma submissão no sentido de "imposições"; há de se valer de táticas antes de se valer de leis "ou, no limite, utilizar ao máximo leis como táticas; fazer de maneira que, por um certo número de meios, tal ou tal fim possa ser alcançado" (FOUCAULT, "La 'governamentalité"”, DE, III, 1994, p. 646).

Diferenciação: se o fim da soberania está em si mesma, o fim da governamentalidade está "nas coisas que ela dirige", na busca da sua perfeição, maximidade ou "intensificação dos processos que dirige" (FOUCAULT, "La 'governamentalité"”, DE, III, 1994, p. 646). Deve haver um saber daquele que governa, mas não um saber entendido como "conhecimento das leis humanas e divinas", da justiça e equidade; o saber que se fala agora se relaciona com a habilidade para se governar "as coisas", seus objetivos e os meios para consegui-los (FOUCAULT, “La 'governamentalitée”, DE, III, 1994, p. 647).

Foucault sintetiza tudo isso dizendo que a partir do século XVI e início do XVII a arte de governar se liga a uma "razão de 
Estado"; o Estado deve ser gerido baseado em leis racionais. Mas isso encontra entraves, como a Guerra dos Trinta Anos, crises financeiras etc. Outros processos histórico-sociais, como a expansão demográfica do século XVIII e todos os problemas, inclusive de saúde, aí presentes, ligados entre si à abundância monetária e aumento da produção agrícola proporcionaram o passo seguinte da governamentalidade: estender a arte de governar a ciências como a economia e estatística, doravante fazendo com que "o problema do governo pudesse, enfim, ser pensado, refletido e calculado fora do quadro jurídico da soberania (FOUCAULT, "La 'governamentalité'"'”, DE, III, 1994, p. 651).

No curso "Securité, territoire, population" (FOUCAULT, DE, III, 1994, p. 719) Foucault mostra justamente como vai acontecer aí uma espécie de retorno ao estoicismo, desde o pendor para governar-se a si mesmo, retomado pela pastoral cristã, ao governo das crianças, posto pela pedagogia; depois, em outro lugar aparece o governo em relação a outrem, desenvolvido pelo príncipe (FOUCAULT, “'La gouvernementalité'", DE, III, 1994, p. 636). Só que, enquanto cabia ao príncipe governar segundo as inúmeras virtudes tradicionais (justiça, respeito às leis divinas, prudência etc.), a nova "razão de Estado" deverá se valer de uma tecnologia diplomáticomilitar: agora, a força de um Estado deve estar assegurada pelas suas alianças e de seus exércitos, além de um aparelho policial responsável por fazer "crescer" interiormente a força estatal.

Mas polícia como expressão tomada em um sentido bastante largo: trata-se de "um conjunto de meios necessários para fazer aumentar, do interior, as forças do Estado" 
(FOUCAULT, "Sécurité, territoire et population", DE, I 1994, p. 721). Em outro lugar ele conceitua a polícia como "O conjunto dos meios que é necessário para assegurar, além da tranqüilidade e da boa ordem, o 'bem público'” (FOUCAULT, "La politique de la santé au XVIII siècle", DE, III, 1994, p. 728). A polícia é, portanto, uma técnica de governo que propicia a este intervir na sociedade e que tem a ver com a manutenção da "potência" e do "vigor" do Estado, propiciar as relações de trabalho e comércio entre os homens, assegurando a sua "comunicação", também aqui em sentido largo: tudo que faça o homem viver, sem a qual a vida "seria precária, miserável e perpetualmente ameaçada" (FOUCAULT, “'Omnes et singulatim"': vers une critique de la raison politique", DE, IV, 1994, p. 153$){ }^{40}$

A governamentalidade nascera, pois, dessas três direções: do modelo "arcaico" da pastoral cristã, da tecnologia diplomático-militar do Estado e da polícia (FOUCAULT, “'La gouvernementalité'", DE, III, 1994, p. 657), ao lado de todo o seu "paradoxo"; pois, em nome da vida dos indivíduos, querendo velar por sua saúde física e mental, não foram muitos os massacres assinados por essa Razão de Estado (FOUCAULT, “Foucault étudie la raison d'État", DE, III, 1994, p. 802)?

Em geral a família deixa de ser o "modelo quimérico do bom governo" para tornar-se "instrumento privilegiado para o governo das populações"; ela aparece no interior desta, e sua importância decisiva será na medida em que, para obter algo da população relativamente ao comportamento

40 Foucault mostra a diferença do Estado, as suas metas e preocupações relativamente àquilo que tinha a ver com o príncipe, como em Maquiavel: o Estado deverá ter, por exemplo, uma duração infinita... 
social, demografia, crianças, consumo etc. - são os exemplos dados por Foucault - é da família que se precisará passar (FOUCAULT, “La 'governamentalitée”, DE, III, 1994, p. 651). Com a população em evidência nascem novas táticas e técnica do governo.

Daí a emergência do importante tema da disciplina, algo requisitado no momento em que se buscou gerir a população, o que significava não apenas gerir a "massa coletiva dos fenômenos [ou gerir] ao nível de seus resultados globais; gerir a população, isso quer dizer gerir igualmente em profundidade, com fineza e no detalhe" (FOUCAULT, "La 'gouvernementalité"”, DE, III, 1994, p. 654). O círculo ora instalado é, então, soberania-disciplina-gestão, tendo a segunda como elemento fundamental e os seus mecanismos essenciais sendo os dispositivos de segurança (FOUCAULT, “La 'governamentalité'", DE, III, 1994, p. 654).

Em resumo, Foucault entende por governamentalidade: 1) um conjunto de "instituições, procedimentos, análises e reflexões, cálculos e táticas" que permitem ao poder exercerse, tendo como alvo a população, e sendo os dispositivos de segurança o instrumento técnico maior; 2) a tendência de um governo endereçado aos outros (mas também um governo de si de por si), apontando à soberania e à disciplina; 3) o "resultado de um processo", qual seja, a transformação do estado de justiça medieval (voltado para as leis costumeiras ou escritas) em estado administrativo, depois em estado de governo, não definido pelo território, mas pela população que o habita (FOUCAULT, “La 'Gouvernementalité'”, DE, III, p. 655).

Em suma, a governamentalidade deve se referir, sobretudo (mas aí o seu sentido se alarga ainda mais, encontrando 
maior guarita na fase foucaultiana da genealogia da ética), à "maneira de dirigir a conduta de indivíduos ou de grupos: governo das crianças, das almas, das comunidades, das famílias, dos doentes" (FOUCAULT, "Le sujet et le pouvoir", DE, IV, 1994, p. 237), muito além de ser apenas um conjunto de conselhos endereçados ao príncipe ou então algo que brote ou engendre uma "'ciência da política'" (FOUCAULT, "La 'gouvernementalité'”', DE, III, 1994, p. 635).

Agora bem, compreendendo o fenômeno da governamentalidade, há de se buscar o reverso: a sua crítica, e é isso o que Michel Foucault almeja. Voltando a atenção ao texto "Qu'est-ce que la critique? [Crítique y Aufklärung]", ao abordar o aspecto da laicização e disseminação da arte de governar, Foucault privilegia aí a emergência do "direito natural". Os homens passam a dirigir suas críticas no sentido de reivindicar os "direitos universais e imprescindíveis" aos quais todos devem seguir, desde os governantes aos educadores e padres. Com isso, existe uma não aceitação de supostas leis (injustas), não importa se vindas mesmo do soberano. O que importa é fazer prevalecer aqueles direitos evocados acima, e a crítica mostra o seu rosto toda vez que tais princípios não são seguidos.

Um terceiro momento naquele texto, já mencionado neste trabalho é aquele em que Foucault se refere ao 'não querer ser governado' como "não aceitar como verdade o que uma autoridade disse que é verdade" (FOUCAULT, 1995, p. 4). Sintetizando esses três momentos vê-se a existência de uma tríplice correspondência: "a Bíblia, o direito, a ciência; a escritura, a natureza, a relação consigo mesmo; o magistério, a lei, a autoridade do dogmatismo" (FOUCAULT, 1995, p. 4). 
Governar outrem não quer significar, contudo, rebaixar o indivíduo a um patamar de submissão absoluta. É verdade que o poder utiliza suas técnicas e táticas (é uma "arte" justamente por isso). Essa "arte" correlativa a táticas e técnicas pode se dar seja diretamente: campanhas governamentais, por exemplo - seja indiretamente: estímulos à natalidade, à produção de algo etc., sem que alguém perceba isso necessariamente (FOUCAULT, "'La gouvernementalité'”, DE, III, 1994, p. 652); e cabe a ela escalonar cada indivíduo segundo um sistema diferencial complexo (diferenças jurídicas, econômicas, de lugar nos processos de produção, lingüísticas e culturais, de competência etc.); ${ }^{41}$ Mas Foucault também diz pressupor nesse processo sujeitos livres inseridos em cada sistema e em cada disputa, sujeitos cujas ações, comportamentos, decisões não estão fixadas de uma vez por todas.

Ora, se uma reação será sempre possível, a crítica também o será, compondo com o aspecto da liberdade a própria "condição de existência do poder", contanto que se entenda isso não como um antagonismo necessário entre as partes (se há poder, não há liberdade), senão como um "agonismo" [agonisme], que já aponta à luta, recorrendo à tradução do latim, mas que Foucault o enriquece: "uma relação ao mesmo tempo de incitação recíproca e de luta; menos de uma oposição termo a termo que os bloqueia um em face do outro, do que

41 Em "Le sujet et le pouvoir" (FOUCAULT, DE, IV, 1994, p. 240), além desse "sistema de diferenciação" há ainda nessa análise do poder o "tipo de objetivo", as "modalidades instrumentais" (o poder pode ser exercido pela força das armas, da palavra, de vigilância etc.), as "formas de institucionalização" (família, escola, exército etc.), os "degraus de racionalização (haja vista o exercício do poder ter as suas elaborações e cuidados). 
de uma provocação permanente" (FOUCAULT, "Le sujet et le pouvoir", DE, IV, 1994, p. 238). Por isso o poder estatal, especificamente falando, não deve ser analisado como um poder que recorre a guerras ou a imposições baseadas em determinações jurídicas.

Em outras palavras, se um poder qualquer hegemônico não se cansa de afrontar liberdades, sujeitos livres, detentores eles também de alguma forma de poder, não se cansam de afrontar aqueles poderes. Para Foucault é esta inclusive a condição para que se possa compreender a dinâmica da vida em sociedade; ou seja, entendendo as práticas dos indivíduos como ações sobre outras ações. Fora isso, é uma "abstração". Se se quer uma aproximação conceitual foucaultiana, por mais geral que seja, é só lembrar com ele, ainda em "Le sujet et le pouvoir", que a liberdade é "intransitiva" (FOUCAULT, "Le sujet et le pouvoir", DE, IV, 1994, p. 239): assim como não podemos pedir que alguém ande por nós, não se pode também pedir que um outro assuma o componente de liberdade peculiar a cada um, intrínseco e não delegável. Por seu turno, também não é de bom tom esperar que algum tipo de libertação venha através das diversas instituições existentes ou das leis. "A liberdade é uma prática", diz textualmente Foucault (FOUCAULT, “Espace, savoir et pouvoir", DE, IV, 1994, p. 275). A liberdade é alguma coisa que deve ser exercida, mesmo porque a confiança foucaultiana nos finos propósitos anunciados pelas instâncias institucionais e jurídicas nunca se fez valer.

A contrapartida da governamentalidade será a possibilidade da crítica, uma vez que esta possui como virtus a "não servidão voluntária" ou a "arte da indocilidade reflexiva" (FOUCAULT, 1995, p. 5), como se escreveu mais atrás, até 
porque "esse conjunto de procedimentos, de técnicas, de métodos que garantem a condução dos homens uns pelos outros [me] parece, hoje em dia, em crise, tanto no mundo ocidental quanto no mundo socialista" (FOUCAULT, "Entretien avec Michel Foucault", DE, IV, 1994, p. 93). Mais a frente ele diz: "Nós estamos talvez no início de uma grande crise de reavaliação do problema do governo" ("Entretien avec Michel Foucault", DE, IV, 1994, p. 94);

Essa reavaliação por parte de Michel Foucault pode ser ilustrada nessa importante passagem:

[...] o jogo da governamentalização e da crítica, um com respeito ao outro, dão lugar a fenômenos que são, creio, chaves na história da cultura ocidental [...]. Porém, sobretudo, vê-se que o núcleo da crítica é, essencialmente, o feixe de relações que atam o poder, a verdade e o sujeito, um a outro, ou cada um aos outros dois (FOUCAULT, 1995, p. 4).

Outra passagem importante na seqüência da citação acima tem igualmente um lugar imprescindível:

[...] a crítica é o movimento por meio do qual o sujeito se apropria do direito de interrogar a verdade sobre seus efeitos de poder e ao poder sobre seus discursos de verdade. Em outras palavras, a crítica será a arte da não servidão voluntária, a arte da indocilidade reflexiva. A crítica teria essencialmente por função a des-subjetivação no jogo do que podemos chamar a 'política da verdade' (FOUCAULT, 1995, p. 5). 
Reservou-se para o próximo capítulo desta tese a posição foucaultiana específica acerca da (sua) crítica, quando haverá a oportunidade de discorrer sobre a relação poderverdade-sujeito. Ora, diante do tema da governamentalização importa, pois, empreender uma crítica voltada na contramão dos processos individualizantes que se seguiram àquelas práticas e técnicas. Isso requer ir além de posições encontradas comumente. É o que transparece em "Qu' est-ce que la critique? [Crítique y Aufklärung]", onde Foucault tenta, sem desconsiderar a posição de outros autores (como Dilthey ou Habermas, segundo Michel Foucault), emitir um entendimento particular da obra kantiana, a partir de uma investigação histórico-filosófica. Foucault, neste sentido, faz uma tentativa de sair da relação Aufklärung/conhecimento, que constantemente foi estabelecida, ou seja, da "indagação sobre a legitimidade dos modos históricos do conhecer", a favor da entrada do problema do poder. A citação abaixo é bastante esclarecedora:

O que se busca, então, não é saber o que é certo ou falso, fundamentado ou não, real ou ilusório, científico ou ideológico, legítimo ou abusivo. O que se busca é saber quais são os laços, as conexões, que podem ser desencobertas, entre mecanismos de coerção e elementos de conhecimento; os jogos de envio mútuo e de apoio que se desenrolam entre esses mecanismos e estes elementos; o que faz com que um certo elemento de conhecimento possa tomar efeitos de poder ao estar inserido em um sistema como um elemento verdadeiro, provável, incerto ou 
falso, e o que faz com que um certo procedimento de coerção adquira a forma e as justificações próprias de um elemento racional, calculado, tecnicamente eficaz, etc. (FOUCAULT, 1995, p. 13).

É que se deu muito mais atenção no século XIX (mas ao XX também) "à continuação da empresa crítica (...) do que à Aufklärung mesma" (FOUCAULT, 1995, p. 7). Nessa análise Michel Foucault chega a identificar o surgimento de três traços fundamentais: de uma ciência positivista, fundada sobre uma confiança em si mesma, bem como de uma cuidadosa "crítica em relação a cada um dos seus resultados" (FOUCAULT, 1995, p. 7); o desenvolvimento de um estado ou sistema estatal como expressão de racionalidade na administração da sociedade humana; uma ciência de um estado, ou estatismo, tendo em vista que esta ciência vai representar "um papel cada vez mais determinante no desenvolvimento das forças produtivas", ganhando importância também "na medida em que os poderes de tipo estatal vão exercer-se cada vez mais através de conjuntos técnicos refinados" (FOUCAULT, 1995, p. 7). ${ }^{42}$

A relação crítica-Aufklärung relevante em toda essa empreitada para Foucault é outra, porém. Michel Foucault vai falar de

42 Acerca desse terceiro traço é possível tomar de empréstimo os vários estudos feitos por Foucault anteriormente, colocando a ciência não propriamente ao lado de uma empreitada neutra, por assim dizer, de um ideário ligado ao conhecimento e à verdade, senão do lado de todo um conjunto institucional que cabe a ela fornecer as justificativas e os apoios técnicos. Isso se deu, sobretudo, com a Histoire de la folie (2003a), com Naissance de la clinique (2003b) e com Surveiller et punir (2003f), chegando mais à frente com os três volumes da Histoire de la sexualité: La volonté de savoir, (2003c), L'usage des plaisirs (2003d) e Le souci de soi (2002c).. 
uma "maneira legítima" pela qual os termos vão se relacionar, e essa maneira tem a ver com uma "postura de desconfiança ou, em todo caso, de uma interrogação cada vez mais de suspeita" (FOUCAULT, 1995, p. 7). O que pode resumir tal postura, segundo ele, é a resposta à pergunta: “De quais excessos de poder, de qual governamentalização [...] não é essa mesma razão historicamente responsável?" (FOUCAULT, 1995, p. 7). Especificamente sobre esta questão o seu "devir" tomara caminhos distintos na Alemanha e na França.

A Alemanha empreendeu uma crítica à racionalização, cabendo destaque a emergência de uma esquerda hegeliana, que se estendeu até a Escola de Frankfurt, com suas suspeitas ou críticas ao positivismo, ao objetivismo, à racionalização e ao tecnicismo, tratando-se aí "de uma crítica do projeto fundamental da ciência e a técnica tendo como objetivo fazer aparecer as conexões entre uma presunção ingênua da ciência, por uma parte, e as formas de dominação próprias da conformação da sociedade contemporânea, por outra" (FOUCAULT, 1995, p. 8).

Tal inclinação se estendeu a autores como Husserl, a exemplo da sua obra de 1936, que versou sobre a crise da humanidade européia, justamente na relação questionável entre conhecimento e técnica. Nesta obra Husserl vai achar "um absurdo considerar a natureza do mundo circundante como algo por si alheio ao espírito e então querer fundamentar, em conseqüência, a ciência do espírito sobre a ciência da natureza e fazê-la, assim, pretensamente exata" (HUSSERL, 2002, p. 69).

Para Michel Foucault na França houve um movimento crítico diferente e de menor envergadura, se comparado à 
Alemanha. Nessa comparação duas expressões devem chamar a atenção. Foucault vai se referir a críticas endereçadas a uma "razão presunçosa" e aos seus "efeitos específicos de poder" que ela engendra. Esta já é uma clara indicação das relações que ele tentou estabelecer ao longo da sua démarche filosófica entre saber e poder. Para ele a França se aliou, ao contrário, a um pensamento de direita, desde o século XIX à primeira metade do XX, embora com "a mesma acusação histórica à razão ou à racionalização em nome [daqueles] efeitos de poder" (FOUCAULT, 1995, p. 8).

Nessa apropriação do significado da Aufklärung menos "ampla" e com menos "alcance" a peculiaridade da França residiu no fato de que "nos conformamos com uma certa valorização política dos filósofos do século XVIII ao tempo em que se desqualifica o pensamento da Ilustração como um episódio menor na história da filosofia" (FOUCAULT, 1995, p. 8), coisa que não se verificou na Alemanha. Ao contrário, aí a Aufklärung chegou a representar a "manifestação espetacular do profundo destino da razão ocidental" (FOUCAULT, 1995, p. 8).

A partir da segunda metade do século XX Foucault aponta uma certa transformação desse quadro na França relativamente à Aufklärung, "graças à fenomenologia e aos problemas que ela coloca" (FOUCAULT, 1995, p. 9). A Fenomenologia, fazendo uma pergunta acerca da noção de "sentido", abre com isso um espaço inevitável para uma sua contrapartida. Ou seja, "Como é que o grande movimento da racionalização nos conduziu a tanto ruído, a tanto furor, a tanto silêncio e mecanismo sombrio?" (FOUCAULT, 1995, p. 9). Foucault faz lembrar que A Náusea de Sartre é praticamente contemporânea da Crise, de Husserl. Lê-se em uma das partes finais 
do Romance sartreano essa abertura sem fundamento que é a existência humana. Seu personagem, Roquentin, reflete a dado momento:

Trinta anos! E 14.400 francos de renda. Cupões a receber todos os meses. No entanto não sou um velho! Que me dêem alguma coisa para fazer, qualquer coisa... Melhor seria que pensasse em outra coisa, porque nesse momento estou representando para mim mesmo. Sei muito bem que não quero fazer nada: fazer alguma coisa é criar existência - e já há existência suficiente sem isso (SARTRE, 1986, p. 251).

Como escreveu certa vez Merleau-Ponty relativamente a esta análise "formal" do sentido "A linguagem significa quando, em vez de copiar o pensamento, deixa-se desfazer e refazer por ele. Traz seu sentido como o rastro de um passo significa o movimento e o esforço de um corpo" (MERLEAUPONTY, 1991, p. 45). Há de se buscar, na "existência" concreta do sujeito, a articulação entre o seu pensare a sua expressão. Ao que Foucault opõe o conceito de "experiência": a sua análise sobre a história da loucura foi uma visão dessa "experiência" como uma correlação entre "dominios de saber, tipos de normatividade e formas de subjetividade (FOUCAULT, "Usage des plaisirs et tecniques de soi", DE, IV, 1994, p. 538); ou seja, experiência como jogos de verdade ou "conjunto de regras de produção de verdade" (FOUCAULT, "Léthique du souci de soi comme pratic de la liberté", DE, IV, 1994, p. 725), relações de poder e formas de relação a si (FOUCAULT, "Polémique, politique et problematisations", DE, IV, 1994, p. 596); ainda mais, experiência como uma "ficção", algo "que se fabrica a 
si", sem obedecer a critérios como verdade ou sentido dado pelo sujeito (FOUCAULT, "Entretien avec Michel Foucault", DE, IV, 1994, p. 45), conceitos que, provisoriamente, não se dará melhor tratamento. ${ }^{43}$

Ora, o relevo filosófico da Fenomenologia recai mais no esforço de perceber a dinâmica interna do movimento expressivo do sujeito e menos em uma preferência pelas condições externas (poderes implicados, contexto histórico-cultural) explicativas para a mudança dos sistemas discursivos e dos valores sócio-culturais. Daí não provocar espanto o crédito foucaultiano dado ao tema da descontinuidade do conhecimento científico, trabalhado pelos historiadores da ciência ou epistemólogos. Afinal, doravante o tema do "sentido" da Fenomenologia poderia aparecer dentro do jogo social e político a ele atrelado, para além dos formalismos relativos à construção do sentido nos processos da criação subjetiva do sujeito.

Como fica, então, a colocação desse "sentido" no rol da tradição crítica do Ocidente, e da França, no caso? "Qu'est-ce que la critique? [Crítique y Aufklärung]" não deixou incólume essa questão e a responde logo em seguida. Em primeiro lugar, a própria noção de "sentido" vai encontrar um outro viés explicativo: este se constitui a partir de "restrições características da maquinaria significante, e graças a análises do

43 Ainda nessa entrevista ele diz recusar a palavra 'enseignement': “Um livro sistemático que aplicava um método generalisável ou que demonstraria uma teoria assentada em ensinamentos. Meus livros não tem exatamente esse valor. São antes incitações [invitations], gestos feitos em público (FOUCAULT, "Entretien avec Michel Foucault", DE, IV, 1994, p. 46); assim, livro-experiencia oposto a um livro-verdade ou livro-demonstração. 
fato de que não há sentido senão por efeitos de coerção próprios de estruturas que, por uma estranha perspectiva, reencontrou-se com o problema entre ratio e poder" (FOUCAULT, 1995, p. 9). Foucault sintetiza isso com a expressão "coerção do significante". Em outras palavras, um conceito não brota de um jogo em que, habilidoso, o filósofo ou cientista o engendra, a partir da depuração de erros e ilusões em prol de uma verdade que então se descortina.

O problema da coerção do significante e o problema dos "efeitos de restrição", associados ao estudo da história das ciências, são efeitos "ligados a sua institucionalização e à constituição de modelos" (FOUCAULT, 1995, p. 9). Foucault chega a estabelecer uma dúvida retórica acerca do alcance da razão ou racionalidade presente na nossa organização social ou econômica; mas não duvida, e pretende por isso realçar a presença excessiva do poder que, apesar de ter encontrado uma "oposição entre as ideologias da violência e a verdadeira teoria científica da sociedade, do proletariado e da história" (FOUCAULT, 1995, p. 10) - e novamente estamos às voltas com uma ironia foucaultiana, na medida em que ele não acreditava no marxismo como verdadeira teoria científica da sociedade (FOUCAULT, 1995, p. 10) - o fato é que é reencontrada as duas formas irmãs de poder: o fascismo e o stalinismo.

Se as análises empreendidas pela história das ciências recolocaram igualmente, ou encontraram certo eco no problema do "sentido", foram sem se prender a uma tradição fenomenológica, ${ }^{44}$ pois ligada a autores como Cavaillès, Bachelard e

44 Em Foucault e a Fenomenologia (2006) Marcos Nalli defende a tese de uma relação de Michel Foucault com esta corrente encontrada especialmente no Prefácio da primeira edição de Histoire de la folie e nos textos 
Canguilhem - justamente ao indagarem acerca do problema da historicidade das ciências. Assim, uma nova pergunta se constitui: "Como nasce e como se forma esta racionalidade (científica), a partir de algo que é outra coisa? E aqui a recíproca e o inverso do problema da Aufklärung: como ocorre que a racionalização conduza ao furor do poder?" (FOUCAULT, 1995, p. 9). Ora, foi justamente nessas perguntas, desenvolvidas propriamente pelos historiadores das ciências, que a questão kantiana foi reativada, como é encontrado em outro texto foucaultiano: "Na França, é sobretudo a história das ciências que serviu de suporte para a questão filosófica sobre o que tinha sido a Aufklärung" (FOUCAULT, "La vie: l'expérience et la science", DE, IV, 1994, p. 766).

Foucault se lembra de Max Weber para quem, diante de uma série de questionamentos acerca da racionalidade ocidental, destaca-se esta: "Que há dessa racionalização em seus efeitos de restrição e, quiçá, de obnubilação, de implantação massiva e crescente - e nunca questionada radicalmente - de um vasto sistema científico e técnico?" (FOUCAULT, 1995, p. 10). Com essa série de questões a conferência “Qu'est-ce que la critique? [Crítique y Aufklärung]" quis, na verdade, conduzir o ouvinte àquilo que Foucault vai entender como o sentido que ele adota ao tomar a Aufklärung como questão, e o primeiro passo é pensar na noção de "prática histórico-crítica", ou "histórico-filosófica", até agora um terceiro caminho distante do primeiro (a Fenomenologia), e mais próximo do segundo (a epistemologia).

"proto-arqueológicos" de Foucault, a exemplo da Introdução de "Le revê et l'existence", de Binswanger ( FOUCAULT, "Introduction", DE, I, 1994, p. 65). Para um aprofundamento daquela relação acima o próprio Nalli cita uma série de obras de referência, algumas delas utilizadas nesta tese (NALLI, 2006, p. 16-17). 
Foucault acha que houve um campo interessante para a sua aplicação desde antes, uma vez que tanto Kant quanto Weber conseguiu mostrar que, quanto à compreensão do nosso tempo, esta-se diante de uma porta em aberto, ou de um lugar com "múltiplas entradas": como se formou o capitalismo? Como é constituído o mundo burguês? Como funciona o sistema estatal? Como surgiu a ciência moderna, com os seus aparatos técnicos? São um manancial privilegiado de questões que, segundo Foucault, mostra o entrelaçamento entre poder, verdade e sujeito.

Mas, afinal, como conceituar a prática histórico-filosófica? Foucault a enumera em duas características: primeiramente, há de se "desubjetivar a questão filosófica recorrendo ao conteúdo histórico e de libertar os conteúdos históricos graças à interrogação sobre os efeitos de poder que os afeta em virtude da verdade que dizem revelar" (FOUCAULT, 1995, p. 11). Nesse sentido, o sujeito e sua consciência plena cedem lugar a acontecimentos históricos voltados para toda uma trama existente entre relações de poder e ideias de verdade alocadas em cada situação.

Em segundo lugar vai haver uma relação necessária e importante entre a prática histórico-filosófica e certo momento histórico, uma "época empiricamente determinável" e "privilegiada", como diz Foucault (1995, p. 11), correspondendo àquela que Kant e Weber chegaram a falar. Mas, então, tratase de deixar de lado o mundo grego ou cristão em favor do século XVIII? O problema não é este. Para Foucault, a questão é "aplicar a qualquer momento da história" a pergunta fundamental da Aufklärung que diz respeito às relações ou conexões entre poder, verdade e sujeito (FOUCAULT, 1995, p. 12). 
É o que será visto no Capítulo III devendo, por hora, tratar de outro assunto, entendendo como se deu a inclinação foucaultiana pela epistemologia, na sequência daquele terceiro traço da governamentalidade: o dogmatismo da verdade e sua recusa.

Foucault é cioso da sua tradição filosófica, e da forma pela qual apropriou-se dela. Até a Segunda Grande Guerra Mundial ele e colegas, com menos de 20 anos, eram apaixonados pelo conceito e pelo 'sistema'; outros, como os da geração de Sartre, eram "generosos" e "curiosos", nutriam paixão pela vida, política e existência. Mas, que havia sentido em tudo, isso era ambíguo, pois soava como "constatação", "ordem" e "prescrição". O corte operado por Foucault, como ele mesmo comenta em "Entretien avec Madeleine Chapsal", deu-se com Lévi-Strauss, em sua análise de sociedades distantes, pondo em revelo aspectos econômicos e históricos (FOUCAULT, "Le pouvoir, une bête magnifique", DE, III, 1994, p. 372), e com Lacan, quanto ao inconsciente, mostrando ambos que o "sentido" era na verdade um "efeito de superfície", sendo o "sistema" aquilo que [nos] "atravessa profundamente" (FOUCAULT, "Entretien avec Madeleine Chapsal", DE, I, 1994, p. 514).

Assim, não haveria um "eu", mas um "se" ["il y a un on"]; e a resposta de Foucault sobre um Sartre, quando coloca a liberdade de delegar um sentido ou escolha "livres", e aqueles que pendiam para a análise do sistema, foi esta: "A tarefa da filosofia [...] é colocar em jogo esse pensamento diante do pensamento, o sistema diante de todo sistema [...]. É o fundo sobre o qual nosso pensamento 'livre' emerge e cintila durante um instante..." (FOUCAULT, "Entretien avec Madeleine Chapsal", DE, I, 1994, p. 515). 
O sentido dessas ideias pode ser encontrado no "Prefácio" que ele chegou a fazer à edição inglesa do livro de Canguilhem, $O$ normal e o patológico, mas que se utiliza aqui o texto de 1985, qual seja "La vie: l'expérience et la science". Encontra-se nesse texto informações e discussões abundantes e importantes, merecendo uma exposição dos seus detalhes. O texto versa sobre o que significou a obra de Canguilhem em relação à herança crítica na França. Mas como compreender esta herança, diante de uma gama tão variada de correntes e perspectivas teórico-metodológicas?

Em primeiro lugar parece que Michel Foucault chegou a identificar lugares comuns em relação à presença de Canguilhem no seu país. "Todo mundo sabe" - inicia-se "La vie...", - que, apesar de ter havido poucos lógicos no quadro universitário francês, não fora "negligenciável" o número de historiadores das ciências. Outro lugar menos comum, porém, é que poucos chegaram a compreender a presença mesma de Canguilhem nos vinte ou trinta anos do seu trabalho na instituição universitária, inclusive para além desta (FOUCAULT, "La vie: l'expérience et la science", DE, IV, 1994, p. 763).

Numa referência à tradição crítica na França Foucault faz lembrar as correntes de pensamento que tiveram vez no quadro da sua intelectualidade, como o marxismo, a psicanálise, a lingüística e a etnologia ("espetáculos mais ruidosos" do saber), além da sociologia, de temas relativos ao funcionamento da instituição universitária ou ao sistema de valores culturais. Para Michel Foucault o papel da filosofia "em todas as discussões políticas ou científicas desses estranhos anos 60 [...] foi importante", embora deva-se ter o cuidado de saber que elas foram conduzidas não propriamente por filósofos 
que obtiveram uma formação filosófica nos departamentos de filosofia, senão por aqueles que, de alguma forma, ativaram a prática filosófica em suas áreas de competência.

Esboçado o quadro acima Michel Foucault tenta inserir Canguilhem como peça fundamental em toda essa tradição, e em dois momentos: em primeiro lugar, "direta ou indiretamente, todos ou quase todos esses filósofos tinham relação com o ensino ou com os livros de Canguilhem" (FOUCAULT, “La vie: l'expérience et la science”, DE, IV, 1994, p. 763). E isso "paradoxalmente", uma vez que este autor tinha se voltado para uma temática da história das ciências direcionada para um domínio eminentemente "particular" de investigação, ${ }^{45}$ geralmente de pouco glamour. Em segundo lugar, a presença deste autor é ainda mais excessiva: suprimam Canguilhem e passaremos a "não compreender mais grande coisa" das discussões travadas entre aqueles ramos do saber, nos quais se incluem autores como Bourdieu, Castel e Passeron, além de lacanianos que, no texto, não foram nomeados (FOUCAULT, “La vie: l'expérience et la science", DE, IV, 1994, p. 763).

Um segundo momento interessante na exposição que faz Michel Foucault em "La vie..." é a divisão geral do quadro do pensamento francês, naquilo que houve de mais significativo. Assim, para ele não importava tanto a distinção interna entre aqueles que seriam freudianos ou não, marxistas ou não

45 Canguilhem trabalhou com as "ciências da vida: biologia, anatomia, fisiologia, patologia", mas não no sentido da elaboração de uma filosofia da vida, senão de uma "filosofia das ciências da vida", o que significa isso: "Se ela encerra uma reflexão sobre a vida - o que não se pode negar - tal reflexão é indireta e mediatizada, faz-se através da análise do tipo de racionalidade das ciências que a constituem como objeto" (MACHADO, 2006, p. 15). 
marxistas etc., mas identificar "uma linha divisória que atravessa todas essas oposições". Desse modo, escreve o autor, houve uma linha que separava

[...] uma filosofia da experiência, do sentido, do sujeito e uma filosofia do saber, da racionalidade e do conceito. De um lado, uma filiação que é a de Sartre e de Merleau-Ponty; e depois uma outra, a de Cavaillès, Bachelard, Koyré e Canguilhem (FOUCAULT, “La vie: l'expérience et la science", DE, IV, 1994, p. 764).

Mas de onde eles partiram? "La vie..." tenta identificar esse recuo a partir do século XIX, em que aparecem os pares Bergson/Poincacaré, Lachelier/Couturat, Maine de Biran/Comte. No século XX a obra de referência é o texto de E. Husserl Meditações cartesianas, publicadas em 1929, que recebeu duas leituras: a primeira, atrelada a uma filosofia do sujeito, encontrando guarida em Ser e tempo, de Heidegger, mas, sobretudo em Transcendance de l'ego, de Sartre (1992); a segunda, voltada para questões de formalismo e intuicionismo em relação à obra de Husserl, vão redundar nas teses de Cavaillès (FOUCAULT, "La vie: l'expérience et la science", DE, IV, 1994, p. 764).

Uma interpretação foucaultiana curiosa aparece, então: "aparentemente", a linha partilhada por Cavaillès foi mais teórica, pois "mais regrada em relação às tarefas especulativas". Como entender isso? Esse problema praticamente kantiano de uma teoria que vai além dos seus limites foi pensada por Foucault em vários momentos; cita-se, por exemplo, o 
caso de autores que quiseram fazer uma filosofia totalizante. Assim, na entrevista "Le grand enfermement", ao perguntarem a Foucault se havia filósofos sérios que totalizaram, como Sartre, sua resposta foi afirmativa, seguida de um "longo silêncio". Sim, ele é sério, mas "em toda parte onde Sartre totaliza, ele se afasta da realidade. E cada vez que ele se apodera de um problema determinado, que ele tem uma estratégia determinada, que ele luta, aproxima-se da realidade" (FOUCAULT, "Le grand enfermement", DE, I, 2001, p. 1173). Totalizar, como aparece agora no artigo "Sur l'archéologie des sciences. Réponse au cercle d'épistémologie", é também "querer fazer da análise histórica o discurso do contínuo", da consciência humana o sujeito originário de todo saber e prática (FOUCAULT, "Sur l'archéologie des sciences. Réponse au cercle d'épistémologie", DE, I, 2001, p. 727).

"Aparentemente" também a filosofia de Cavaillès esteve mais afastada de preocupações "políticas imediatas" do que a primeira linha. Ora, numa posição contrária a isso Foucault acredita que foi ela que, justamente durante a guerra, voltouse diretamente para questões ligadas ao fundamento da racionalidade, compreendendo que isso não devia ser apartado do problema das "condições atuais de sua existência"; por fim, foi ela que entendeu que a "crise" não residia apenas na universidade, mas dizia respeito igualmente ao "status e papel do saber" (FOUCAULT, "La vie: l'expérience et la science", DE, IV, 1994, p. 765).

Michel Foucault utiliza-se de uma expressão bastante forte e positiva neste ínterim: para ele, o que fez da história das ciências a sua "dignidade filosófica" (FOUCAULT, "La vie: l'expérience et la science", DE, IV, 1984, p. 765) foi a retomada 
do projeto kantiano. Como Foucault o sintetiza para além daquilo que já foi dito na primeira parte deste capítulo,

Pela primeira vez, nessa época [século XVIII], questionou-se o pensamento racional não somente sobre sua natureza, seu fundamento, seus poderes e direitos, mas sobre sua história e sua geografia, sobre seu passado imediato e suas condições de exercício, sobre seu momento, lugar e atualidade (FOUCAULT, "La vie: l'expérience et la science", DE, IV, 1994, p. 765).

A retomada do referido projeto kantiano fora reativado desde Saint-Simon ao positivismo de Comte, com seus sequazes, por unir tanto a temática da história quanto associá-la às manifestações científicas ou mesmo sociais:

Saber e crença, forma científica do conhecimento e conteúdos religiosos da representação, ou passagem do pré-científico ao científico, constituição de um poder racional sobre um fundo de uma experiência tradicional, aparecimento, no seio da história, das ideias e das crenças, de um tipo de história característica do conhecimento científico, origem e limiar da racionalidade: é sob essa forma que, através do positivismo - e daqueles que se opuseram a ele -, através dos debates acalorados sobre o cientificismo e das discussões sobre a ciência medieval, a questão da Aufklärung foi transmitida na França (FOUCAULT, “La vie: l'expérience et la science", DE, IV, 1994, p. 766). 
Para Michel Foucault, ainda retomando a entrada de Husserl na França, se a Fenomenologia deixou brandamente de silenciar-se em relação ao projeto kantiano foi quando, a partir das Meditações cartesianas (2001) ou de A crise da Humanidade européia e a filosofia (2002) pôde se aproximar de algumas análises colocadas por tais textos; precisamente, "a questão das relações entre o projeto ocidental de um desdobramento universal da razão, a positividade das ciências e a radicalidade da filosofia" (FOUCAULT, "La vie: l'expérience et la science", DE, IV, 1994, p. 766). Temáticas que, fora da França, encontraram certa correspondência na Escola de Frankfurt, apesar de haver diferenças notáveis entre estilos, formas de fazer e domínios tratados.

Mas o que estaria por detrás de tudo isso? Precisamente, e aí se mostra a correspondência entre os primórdios do criticismo kantiano e a história das ciências, o problema de uma autonomia da razão, diante de possíveis dogmatismos e despotismos, ou então de uma razão libertadora, na condição de que "ela consiga libertar-se" (FOUCAULT, "La vie: l'expérience et la science", DE, IV, 1994, p. 768). O que significa pensar em uma racionalidade destituída de pretensões universais, de unidade ou de "soberania", sem levar em conta, de um lado, as "contingências" históricas do nascimento dessa razão, bem como as "inércias", os "embotamentos" ou as "coerções" de tal razão soberana.

O resultado do empreendimento kantiano foi a problematização da racionalidade no seu duplo aspecto: como despotismo e esclarecimento, como razão libertadora e opressora. Assim, pode a ciência reivindicar algo como uma "validade universal", ou isso é apenas uma "miragem ligada a uma 
dominação e a uma hegemonia política?" (FOUCAULT, "La vie: l'expérience et la science", DE, IV, 1994, p. 768). Tais questões percorreram a obra de Canguilhem, para Foucault, e isso mostra os argumentos comprobatórios de sua presença "central" no cenário intelectual francês.

Mas uma série de objeções a essa linha comum entre Canguilhem ou os epistemólogos e a proposta foucaultiana cabe ser destacada. Mais à frente dos escritos desta tese é ela que se somará em algum momento à ideia de que Foucault tanto colocara "num mesmo saco", como se diz vulgarmente, a si mesmo e uma parte da tradição filosófica francesa inadvertidamente quanto, por tal motivo, precisará ir adiante, acrescentando outras "assinaturas" ou outros personagens conceituais ao traço de "crítico" do qual assumira.

Segundo autores como Roberto Machado, em Michel Foucault, a ciência e o saber (2006), que segue de perto essa questão, caberia realçar, ao contrário, uma distinção, ou, mais precisamente, "um progressivo distanciamento das teses epistemológicas" de Foucault. É verdade que os epistemólogos precisaram situar-se "em uma perspectiva filosófica" do problema da historicidade das ciências, não estando alocados os seus trabalhos em disciplinas "propriamente históricas ou científicas" (MACHADO, 2006, p. 7). Ainda assim, porém, que a ciência tenha uma história atrás de si para os epistemólogos não significa que ela tenha deixado de ser o lugar do conhecimento e da verdade, o lugar mais avançado até no âmbito da racionalidade e, por fim, que, de alguma forma, não se possa desconsiderar a noção de progresso científico. Em uma palavra, direções bastante estranhas para Michel Foucault. 
A Introdução de Canguilhem da sua obra Etudes d'histoire et de philosophie des sciences (2002) aborda, de forma geral, todas essas ideias mencionadas por Roberto Machado. Nessa obra de Canguilhem, cuja Introdução traz como título "Le objet de l'histoire des sciences", sendo uma conferência que fez em 28 de outubro de 1966, a pergunta inicial que faz é: "de que a história das ciências é história?" (CANGUILHEM, 2002, p. 9). Canguilhem defende uma relação sui generis dessa nova disciplina, que junta história das ciências e filosofia, uma não podendo prescindir da outra. Nessa junção obviamente aparece a necessidade de tematizar o significado dessa historicidade das ciências e a epistemologia toma para si o modelo do "juiz".

Para Canguilhem, o primórdio do seu início se deu com Descartes: "Sem Descartes, sem a ruptura da tradição, uma história da ciência não pode começar" (CANGUILHEM, 2002, p. 17). Mas é o próprio Descates quem também defende que "o saber é sem história", uma vez que se trata de buscar uma verdade definitiva e irrefutável sobre as coisas, modus geométrico, donde a importância fundamental de Newton na sua crítica ou "refutação da cosmologia cartesiana". Fazendo isso, Newton abre caminho para o entendimento de que a historicidade da ciência é uma sua dimensão inalienável. Canguilhem pode, então, concluir: "A história das ciências é a tomada de consciência explícita, exposta como teoria, do fato de que as ciências são discursos críticos e progressivos para a determinação do que, na experiência, deve ser tido como real" (CANGUILHEM, 2002, p. 17, grifo nosso).

Qual o teor dessa "crítica" epistemológica? Na sequência da sua conferência Canguilhem, primeiro, rechaça a posição 
"externalista". Contra a inserção da ciência no quadro dos seus entornos sociais, políticos, econômicos etc., responde o autor: "A atitude crítica de suas questões e de suas respostas, eis o objeto próprio da história das ciências, o que basta para afastar a objeção possível da concepção externalista" (CANGUILHEM, 2002, p. 19). Nesse sentido, importa trabalhar a historicidade dos conceitos no plano propriamente conceitual em que eles se alojam.

Em segundo lugar, e isso já marca outro distanciamento claro em relação a Foucault, pala além das ideias veiculadas acima: progresso da ciência e abordagem internalista - a busca pela verdade ainda permanece sendo o mote das pesquisas científicas na visão de Canguilhem, por mais que tal conceito seja limado das suas notações idealistas. Assim, diz ele,

\begin{abstract}
A história das ciências concerne uma atividade axiológica, a investigação [recherche] da verdade [...]. Assim, a história das ciências, história da relação progressiva da inteligência à verdade, esconde ela mesma seu tempo, e ela o faz diferentemente segundo o momento do progresso a partir do qual ela se dá por tarefa reanimar, nos discursos teóricos anteriores, o que a linguagem de hoje permite ainda compreender (CANGUILHEM, 2002, p. 19-20).
\end{abstract}

Em seu estudo sobre as ciências da vida de Canguilhem a Foucault, homônimo, Vera Portocarrero, tomando a noção de "vitalismo" para ilustrar isso encontra muitas situações para descrever o objeto de estudo e método da epistemologia 
e da arqueologia foucaultiana, ratificando a tese de Roberto Machado. Diz ela,

\begin{abstract}
A história das ciências tem de analisar o erro, distinguindo o inerte e o ativo, o nocivo e o fecundo. A verdade se dá no interior do discurso, num processo cuja historicidade é constituída no movimento de verdade e erro. O elemento que exprime primordialmente sua normatividade é o conceito, cuja historicidade constitui o objeto da epistemologia (PORTOCARRERO, 2009, p. 116, grifo nosso).
\end{abstract}

Mas o fundamental nessa questão do vitalismo é que, para Portocarrero, "é surpreendente a diferença do valor conferido a esse tema pela epistemologia de Canguilhem e pela história de Jacob, por um lado, e pela arqueologia de Foucault, por outro" (PORTOCARRERO, 2009, p. 107). Especificamente para este último, diz Portocarrero, "o vitalismo tem o valor apenas de efeito de superfície que diz respeito a uma camada mais fundamental do saber, a episteme" (PORTOCARRERO, 2009, p. 107).

Tomando agora em outro autor da torrente epistemológica, Gaston Bachelar, ver-se-ia que suas ideias chacelam as linhas diretrizes até aqui colocadas, a saber, crença em uma verdade, ou em uma aproximação progressiva desta através do trabalho das ciências e, concomitantemente, uma certa noção de progresso. Em A formação do espirito científico (BACHELARD, 1996, p. 11) Bachelard descreve em termos de "obstáculos" as diversas formas de conhecimento na direção da ciência, algo 
que serve também para marcar diferença entre o historiador da ciência e o epistemólogo:

O historiador da ciência deve tomar as ideias como se fossem fatos. O epistemólogo deve tomar os fatos como se fossem ideias, inserindo-as num sistema de pensamento. um fato mal interpretado por uma época permanece, para o historiador, um fato. Para o epistemólogo, é um obstáculo, um contra-pensamento (BACHELARD, 1996, p. 22).

Em outro momento Bachelard, parafraseando Comte, fala de "uma espécie de lei dos três estados para o espírito científico". Assim, a ciência surge após ficarem para trás o "estado concreto, em que o espírito se entretem com as primeiras imagens do fenômeno"; o "estado concreto-abstrato, em que o espírito acrescenta à experiência física esquemas geométricos e se apoia numa filosofia da simplicidade"; e o "estado abstrato, em que o espírito adota informações voluntariamente subtraídas à intuição do espaço real, voluntariamente desligadas da experiência imediata e até em polêmica declarada com a realidade primeira, sempre impura, sempre informe" (BACHELARD, 1996, p. 11).

Nesse texto Bachelard realça, pois, a diferença e mesmo a contradição entre experiência científica e experiência comum, esta não podendo ser "efetivamente verificada", permanecendo um fato e não podendo "criar uma lei". É certo que a ciência se faz por meio de precisões e retificações; ainda aí, contudo, isso traduz a sua historicidade, não sendo demérito 
algum estar sempre problematizando, sempre questionando; afinal de contas, o saber ao qual procura a ciência só é um ponto provisório de chegada. Se ela "deseja saber [é para] imediatamente, melhor questionar" (BACHELARD, 1996, p. 21).

Parece, pois, que se é levado muito naturalmente a acreditar nesse "fosso" entre a epistemologia e Michel Foucault. E, de fato, este mesmo chegou a marcar uma distinção entre um conceito de ciência e um conceito de "saber", não podendo, pois, inserir-se plenamente naquela tradição epistemológica. Assim, L'archéologie du savoir chega a dizer:

A prática discursiva não coincide com a elaboração científica a que pode dar lugar; e o saber que ela forma não é nem o esboço enrugado, nem o subproduto cotidiano de uma ciência constituída. As ciências - pouco importa, no momento, a diferença entre os discursos que têm presunção ou status de cientificidade e os que apresentam realmente seus critérios formais - aparecem no elemento de uma formação discursiva, tendo o saber como fundo (FOUCAULT, 2005, p. 240).

Mas talvez "fosso" seja uma palavra muito forte, tendo em vista a grande valorização que ele fez do trabalho dos epistemólogos, sobretudo com ênfase em Koyré, Bachelard, Cavaillès e Canguilhem. É ainda por guardar certa proximidade entre si que trabalhos como o de Pierre Macherey podem sugerir que há um traço comum entre Canguilhem e Michel Foucault, a saber, "a força das normas" (MACHEREY, 2009, p. 36). Isso porque a epistemologia daquele autor não se volta 
para a ciência no intuito de inventariar as suas conquistas ou descobertas, mas de buscar "seu sentido", sua "razão de ser". Um trabalho filosófico, portanto, que, no caso daquela relação proposta por Macherey, busca mostrar um pararelo entre o le normel et le pathologique (2003), de Canguilhem, e Naissance de la clinique (2003b), de Foucault, ambos tendo em comum o ano de suas publicações (1966) e, sobretudo, "uma crítica radical da pretensão de objetividade do positivismo biológico" (MACHEREY, 2009, p. 102).

Sendo assim, melhor pensar que houve uma relação bastante complexa de Michel Foucault com a epistemologia e o próprio Roberto Machado não deixa de reconhecer isso, ao procurar mostrar aqueles "deslocamentos paulatinos" de uma perspectiva em relação à outra, sem defender algum tipo de corte radical e abrupto. A concentração no âmbito do conceito e certa afinidade temática são sinais dessa proximidade; nesse caso há pensar em uma relação que o próprio Machado certa vez aplicou a Nietzsche, e que poderia ter sido aplicada a Foucault, no sentido de realçar aquela afinidade temática: "A reflexão sobre a ciência, isto é, uma investigação sobre as questões afins do conhecimento, do pensamento, do intelecto, da razão, da consciência, do conceito, da verdade, encontrase no âmago da filosofia de Nietzsche" (MACHADO, 1985, p. 07), ainda que ele não tivesse elaborado "um conceito de ciência" como tal.

Ter sido um herdeiro dessa série de problemas assumido desde Nietzsche; ter oscilado ora entre um afastamento, ora entre uma posição elogiosa de Foucault acerca da epistemologia; ter buscado caminhos distintos aos das filosofias do sentido, experiência e sujeito soberano, em prol de filosofias 
voltadas ao conceito: eis os traços gerais da ligação entre Michel Foucault e a corrente epistemológica. Mas essa será uma relação que se tornará cada vez mais dispersa e longínqua, caso se adentre no âmago de sua posição "crítica" mais particular, tematizando a relação contígua sujeito-verdade -poder, suspeitando, pois, de todas as posições por demais ideais e otimistas acerca dessas noções, e colocando a ciência muito próxima de um artifício reacionário da sociedade, de um lado, e de uma expressão cultural em amplo sentido, do outro. A imagem foucaultiana do "crítico" cada vez mais começará a solicitar outras "assinaturas". 